\title{
Prevention of necrotizing enterocolitis with probiotics: a systematic review and meta-analysis
}

\author{
Sonja C Sawh ${ }^{\text {Corresp., }}{ }^{1}$ ， Santosh Deshpande ${ }^{1}$ ， Sandy Jansen ${ }^{1}$ ， Christopher J Reynaert ${ }^{1}$ ， Philip M Jones ${ }^{2}$ \\ 1 Department of Pharmacy, London Health Sciences Centre, London, Ontario, Canada \\ 2 Departments of Anesthesia \& Perioperative Medicine and Epidemiology \& Biostatistics, University of Western Ontario, London, Ontario, Canada \\ Corresponding Author: Sonja C Sawh \\ Email address: sonja.sawh@Ihsc.on.ca
}

Context Necrotizing enterocolitis (NEC) is the most frequent gastrointestinal emergency in neonates. The microbiome of the preterm gut may regulate the integrity of the intestinal mucosa. Probiotics may positively contribute to mucosal integrity, potentially reducing the risk of NEC in neonates.

Objective To perform an updated systematic review and meta-analysis on the efficacy and safety of probiotics for the prevention of NEC in premature infants.

Data Sources Structured searches were performed in: Medline, Embase, and the Cochrane Central Register of Controlled Trials (all via Ovid, from 2013 to January 2015). Clinical trial registries and electronically available conference materials were also searched. An updated search was conducted June 3, 2016.

Study Selection Randomized trials including infants less than 37 weeks gestational age or less than 2500 $\mathrm{g}$ on probiotic vs. standard therapy.

Data Extraction Data extraction of the newly-identified trials with a double check of the previouslyidentified trials was performed using a standardized data collection tool.

Results Thirteen additional trials $(n=5033)$ were found. The incidence of severe NEC (RR 0.53 [95\% Cl 0.42 to 0.66$]$ ) and all-cause mortality (RR $0.79[95 \% \mathrm{Cl} 0.68$ to 0.93$]$ ) were reduced. No difference was shown in culture-proven sepsis RR 0.88 [95\% $\mathrm{Cl} 0.77$ to 1.00$]$.

Limitations Heterogeneity of organisms and dosing regimens studied prevent a species-specific treatment recommendation from being made.

Conclusions Preterm infants benefit from probiotics to prevent severe NEC and death. 
1 Prevention of necrotizing enterocolitis with probiotics: a systematic review and meta2 analysis

3

4

$5 \quad{ }^{1}$ Sonja C. Sawh, BScPhm, ACPR

$6 \quad{ }^{1}$ Santosh Deshpande, BScPhm

7 'Sandy Jansen, BScPhm, MHS

$8 \quad{ }^{1}$ Christopher Reynaert, B.Sc. Pharm

9 2Philip M Jones, BSc, MSc (Clinical Trials), MD

10

11

\section{Affiliations:} University of Western Ontario, London, ON, Canada

\section{Address correspondence to:}

Sonja Sawh, Pharmacy Department

London Health Sciences Centre

339 Windermere Rd, London ON, Canada

N5A 5A5

sonja.sawh@Ihsc.on.ca 519-685-8500 extension 36543

${ }^{1}$ Pharmacy Department, London Health Sciences Centre, London, ON, Canada

${ }^{2}$ Departments of Anesthesia \& Perioperative Medicine and Epidemiology \& Biostatistics, 


\section{Abstract}

25 Context

26 Necrotizing enterocolitis (NEC) is the most frequent gastrointestinal emergency in neonates. The

27 microbiome of the preterm gut may regulate the integrity of the intestinal mucosa. Probiotics

28 may positively contribute to mucosal integrity, potentially reducing the risk of NEC in neonates.

\section{Objective}

31 To perform an updated systematic review and meta-analysis on the efficacy and safety of 32 probiotics for the prevention of NEC in premature infants.

Data Sources

35 Structured searches were performed in: Medline, Embase, and the Cochrane Central Register of

36 Controlled Trials (all via Ovid, from 2013 to January 2015). Clinical trial registries and

37 electronically available conference materials were also searched. An updated search was

38 conducted June 3, 2016.

\section{Study Selection}

41 Randomized trials including infants less than 37 weeks gestational age or less than $2500 \mathrm{~g}$ on

42 probiotic vs. standard therapy.

\section{Data Extraction}

45 Data extraction of the newly-identified trials with a double check of the previously-identified trials was performed using a standardized data collection tool.

\section{Results}

49 Thirteen additional trials $(\mathrm{n}=5033)$ were found. The incidence of severe NEC $(\mathrm{RR} 0.53$ [95\% CI

500.42 to 0.66$]$ ) and all-cause mortality (RR 0.79 [95\% CI 0.68 to 0.93$]$ ) were reduced. No

51 difference was shown in culture-proven sepsis RR 0.88 [95\% CI 0.77 to 1.00 ].

52

\section{Limitations}

54 Heterogeneity of organisms studied prevent a species-specific treatment recommendation from 55 being made.

\section{Conclusions}

58 Preterm infants benefit from probiotics to prevent severe NEC and death. 
60

61

62 Introduction

63 Rationale

64

65

Necrotizing enterocolitis (NEC) is a gastrointestinal (GI) syndrome characterized by

66

transmural inflammation and necrosis of the large or small bowel and subsequent translocation

67 of gas-forming organisms into the intestinal wall. ${ }^{1,2}$ Primarily seen in infants, the incidence of

68 NEC is inversely correlated with gestational age (GA) and birth weight. ${ }^{3,4}$ The overall incidence

69 of NEC in all infants $\leqq 33$ weeks GA in a survey of Canadian neonatal intensive care units

70 (NICUs) was 5\%, and 7\% for infants less than $1500 \mathrm{~g}$ birth weight in $2013 .{ }^{5}$

71

The consequences of NEC are potentially devastating - $20 \%$ to $40 \%$ of patients require

72 surgical intervention and mortality ranges from $15 \%$ to $30 \% .^{6,7}$ Survivors of NEC risk significant

73 morbidity including short gut syndrome, strictures, and neurodevelopmental impairment. 5,6

$74 \quad$ The signs and symptoms of NEC were classified by Bell in 1978 and gave rise to

75 modified criteria for diagnosis of NEC in 1996 by Neu. ${ }^{7}$ The modified Bell's criteria describe

76 the systemic clinical signs of NEC, the important GI signs (which can help differentiate NEC

77 from sepsis), and the radiologic features.

The immature GI tract of preterm infants is particularly susceptible to mucosal injury

79

80

81

82

83

84 from a variety of factors. Intestinal and immunological deficiencies associated with prematurity, enteral feeding, microbial overgrowth, and circulatory instability have all been implicated in the pathogenesis of NEC. ${ }^{8}$

Recent research has focused on microbial overgrowth in the GI tract of premature infants, with an overabundance of pathogenic organisms and lack of microbial diversity being key discoveries. These observations imply that a disturbance in the microbiome, and not a single 
85 pathogen, may be a causative factor of NEC. ${ }^{9}$ The lower prevalence of protective Lactobacillus

86 or Bifidobacterium species in preterm infants compared to term infants make probiotics a

87 potential intervention for the prevention of NEC. ${ }^{10}$

88

89

90

91

92

93

94

95

96

97

98

99

100

101

102

103

104

105

106

107

108

109

110

111

112

\section{Previous systematic reviews}

At the time of our search, there were two recent systematic reviews and meta-analyses on this topic. ${ }^{11,12}$ The Cochrane review on this topic is thorough, but it was last updated in October $2013^{11}$. The Yang ${ }^{9}$ review included many of the same studies but included additional studies as a result of a Chinese trial database search ${ }^{13-16}$. Since the publication of these two systematic reviews, more large randomized clinical trials have been published.

\section{Objective}

The objective of this systematic review was to assess the efficacy and safety of probiotics for the prevention of NEC in premature infants. We planned to update the previous systematic reviews ${ }^{11,12}$ using similar eligibility criteria.

\section{Methods}

Protocol/registration

The systematic review methods and analysis plans were undertaken according to published guidelines by PRISMA. ${ }^{17}$

\section{Eligibility criteria}

Studies: All randomized clinical trials were considered for inclusion. No language restrictions were applied.

Participants: Infants of less than 37 weeks gestation or weighing less than $2500 \mathrm{~g}$ at birth. Interventions: Probiotics in any species and any dose, or prebiotic/probiotic combinations (synbiotics) of any species and any dose. 
114 Comparators: Probiotic products with different species than the intervention group (i.e. RCTs

115 comparing one species to another head-to-head), placebo, or standard therapy.

116

117

118

119

120

121

122

123

124

125

126

127

128

129

130

131

132

133

134

135

136

137

138

139

140

Outcomes: The primary outcome of the review was the incidence of severe NEC (Bell's Stage 2

or greater). Secondary outcomes included all-cause mortality, all-cause sepsis, culture-proven sepsis, bacterial sepsis, fungal sepsis, length of stay in hospital, time to achieve full feeds, duration of parenteral nutrition, and weight gain.

\section{Outcome definitions}

1. Sepsis was accepted as defined by the authors of the individual trials.

2. Culture-proven sepsis was accepted as defined by the authors but needed to include a positive culture (blood, urine, or cerebrospinal fluid) to qualify.

3. Length of stay in hospital and length of stay in NICU were considered equivalent. Many studies discharged infants home directly from the NICU.

4. We considered the outcome "age at which full enteral feeding was reached" to be the same as "time to reach full feeds". We considered the "age at which parenteral nutrition stopped" to be the same as the outcome of "duration of parenteral nutrition".

5. We subgrouped trials in duration of therapy categories based on the durations reported in the results section of each paper, not the planned duration. We only placed a trial in a specific subgroup if the duration category encompassed the median and the entire interquartile range (IQR) reported in the study paper.

\section{Information Sources \& Search}

\section{Pre-existing trials}

Randomized clinical trials included in the previous systematic reviews ${ }^{11,12}$ (hereafter

referred to as the "old trials") were included in this review. Chinese language studies were 
141 translated to complete the data extraction. ${ }^{13-15,18,19}$ The studies by Romeo ${ }^{20}$ and Underwood ${ }^{21}$

142 were divided into two separate trials due to multiple arms.

143

144

145

146

147

148

149

150

151

152

153

154

155

156

157

158

159

160

161

162

163

164

165

166

\section{Updated Search}

Trials published after completion of the two previous systematic reviews (hereafter referred to as the "new trials") were identified by searches of Medline, Embase, and the Cochrane Central Register of Controlled Trials. The search was developed and conducted by one of the authors. See Supplementary materials Appendix A for the detailed search strategies for the three databases used in this review. Limits were applied to obtain trials from 2013 onwards. No language restrictions were applied.

Updated searches were conducted January 19, 2015. Clinical trial registries were searched on January 14, 2015. Abstracts and conference proceedings were searched on January 15, 2015. On June 3, 2016 another full update of our search strategy was conducted.

We searched for ongoing, unpublished, and terminated trials using the National Library of Medicine and National Institutes of Health clinical trials database and the World Health Organization International Clinical Trials Registry Platform. ${ }^{22,23}$ Other sources included electronically available conference materials (2014) from the Society of Pediatric Research (SPR) and the European Society of Pediatric Research (ESPR). ${ }^{24,25}$

\section{Study selection}

After de-duplication, two reviewers independently screened titles and abstracts for inclusion using a standardized screening tool. Full text screening was completed independently in duplicate by two authors using a full-text screening tool. Cohen's Kappa was used to assess agreement between the two reviewers on the selection of full-text articles for inclusion. ${ }^{26}$ 
167

168

169

170

171

172

173

174

175

176

177

178

179

180

181

182

183

184

185

186

187

188

189

190

191

192

Data collection process \& Data Items

A standardized data collection form was developed a priori and two authors

independently extracted the relevant outcomes and validity criteria from the new trials. The data

pertaining to the old trials, including risk of bias assessment, was extracted by one author.

Disagreements were resolved by consensus and a third party was consulted if necessary. Author

contact was attempted for outcome data in the included trials which was missing or unclear. The complete list of the data extracted from the included trials is included in Supplementary

materials, Appendix B.

Study outcome data published in duplicate was included once, but all versions of the publication were utilized for maximal data extraction. In the event of inconsistency between multiple reports of one study, the peer-reviewed publication was used as the primary data set.

\section{Risk of Bias Within and Across Studies}

Two authors independently assessed the risk of bias for each of the new included studies using the criteria outlined in the Cochrane Handbook for Systematic Reviews of Interventions. ${ }^{27}$ A summary table and a graph for risk of bias were created using Review Manager (RevMan) software. ${ }^{28}$ The risk of bias assessment from the studies included in the previous systematic reviews ${ }^{11,12}$ were double-checked for accuracy by a single author.

\section{Synthesis of Results}

When possible, the results were synthesized using RevMan 5.3. ${ }^{28} \mathrm{~A}$ random effects model $^{27}$ was chosen to account for the clinical and statistical heterogeneity expected when including different species and regimens of probiotics, different neonatal ages and weights, different feeding regimens (breast milk, formula, combination feeding, and parenteral nutrition supplementation as needed), as well as the varied countries conducting RCTs in this area. Relative risks (RRs) with 95\% confidence intervals (CI) were used for dichotomous variables 
193 and mean differences (MDs) with 95\% CIs for continuous variables. If the continuous variables

194 in the studies were measured in different scales, we calculated the standardized mean difference 195 (SMD).

196 Analysis was done on an intention-to-treat (ITT) basis. ${ }^{27}$ If patients discontinued the 197 intervention after randomization, they were still counted in our analysis for outcomes (such as 198 mortality) where this was possible. Author contact was attempted to clarify any missing outcome 199 data.

If trials had two intervention arms, both of which contained a probiotic, both probiotic

201 202 203 204 205 206 207 208

\section{Additional Analysis}

Subgroup analysis was planned a priori for the following subgroups: infant weight

(extremely-low birth weight (ELBW) [less than $1000 \mathrm{~g}$ ] and very low birth weight (VLBW) [less than $1500 \mathrm{~g}$ ]), timing of probiotic initiation, duration of probiotic therapy, sepsis types (including "any sepsis"), and use of breast milk vs. formula for feeding.

arms were included and the number of patients in the comparator arm divided by the number of active arms to prevent double counting. If the trial had two or more intervention arms and only one of them contained a probiotic, the data from the corresponding non-probiotic arm was used as the comparator. ${ }^{27}$ In trials where patients received a co-intervention, the co-intervention had to be present in both the active and control arms to be included.

The $\mathrm{I}^{2}$ statistic was used to quantify statistical heterogeneity (the percentage of total variation across studies due to heterogeneity). Statistical heterogeneity as measured by $\mathrm{I}^{2}$ was described as "small" $(\leq 25 \%)$, "moderate" (between $26 \%$ and $49 \%)$ and "large" $(\geq 50 \%){ }^{29}$ Forest plots were visually inspected for possible sources of heterogeneity. 
218 Results

219 Study Selection

220 The previously published systematic reviews included a total of 37 unique randomized

221 clinical trials. ${ }^{13-15,19-21,30-52}$ Electronic database searches (including the 2016 search update)

222 yielded 475 citations, conference searching yielded 115 citations, and clinical trials database

223 searching yielded 35 citations. After de-duplication, 412 citations remained for title and abstract

224 screening (see Figure 1 for the detailed flow diagram of study selection). Cohen's Kappa was

2250.723 (good agreement) between the two reviewers for selection of new full-text trials for

226 inclusion. ${ }^{53}$ The study by Manzoni $2014^{54}$ was included in our review as it was a randomized

227 extension of a previously published trial. ${ }^{42}$ The ProPrems study was added to the previous review

228 as unpublished data, but is now published and was included in our review. ${ }^{46}$ The updated search

229 in 2016 resulted in a follow up to the Oncel trial ${ }^{55}$ (Akar ${ }^{56}$ ), and new trials by Costeloe ${ }^{57}$

230 (previously on our ongoing trials list), Dilli58, Dutta ${ }^{59}$, Sinha $^{60}$ and Tewari ${ }^{61}$. Three trials

231 included in previous reviews were excluded from our review as they were determined to be non-

232 randomized. ${ }^{62-64}$ The overall updated search added a total of 13randomized controlled trials (two

233 trials split due to multiple arms)with over 5000 new evaluable patients to previous systematic

234 reviews, bringing the total to 42 included trials. ${ }^{18,54,55,57-61,65-68}$

235

236

237

238

239

240

241

242

243

241

\section{Study Characteristics}

When verifying the outcome data included in the previous reviews, a number of

methodological flaws and errors of data synthesis were noted. ${ }^{11,12} \mathrm{~A}$ decision was made to re-

extract the data from the "old trials" instead of re-entering the data from the previously published reviews (see Supplementary materials, Appendix C).

See Table 1 for characteristics of included studies. All studies were conducted in preterm infants admitted to the NICU. Twenty-four studies limited birth weight to $1500 \mathrm{~g}$ or less. Weight 
244 was not part of the inclusion criteria in nine studies. ${ }^{13,18,33,44,45,52,57,59,61}$ Gestational age was not

245 part of the inclusion criteria in five studies but all of these studies had birth weight inclusion

246 criteria for preterm infants less than 1500 g. ${ }^{32,37,39,41,54}$ One trial did not specify gestational age

247 but enrolled babies 1500-2500 g. ${ }^{60}$ Five trials were translated from Chinese for use in the 248 review. ${ }^{13-15,18,38}$

249 Type of feeding was variable across the included trials. Nine trials included infants exclusively 250 fed breastmilk. ${ }^{39,41,49,50,60,61,66,69}$ One trial had infants fed exclusively preterm formula. ${ }^{52}$ The trials 251 published in Chinese did not consistently specify this information on translation. ${ }^{13-15,19,38}$ Costeloe had $25246 \%$ of infants exclusively fed breastmilk, but the rest of the infants had a combination of feeding types. ${ }^{57}$ 253 Overall, the number of trials were split evenly between multiple species and single 254 species probiotics (22 trials each). The Sari trial (Bacillus coagulans formerly known as 255 Lactobacillus sporogenes $)^{51}$ and the Tewari trial (Bacillus clausii $)^{61}$ used single species that were 256 not used in any other trial. Sinha used a multi-organism product containing eight species. ${ }^{60} \mathrm{All}$ 257 studies used a variety of organisms and dose regimens. Comparators were matching placebo, 258 standard therapy, or prebiotics (two trials). ${ }^{54,58}$ There were no trials comparing one probiotic 259 preparation with another, but two trials had multiple arms with different probiotics. ${ }^{20,21}$ One trial 260 used varying durations of probiotics and doses but fit within the range of doses and duration of 261 therapy seen with all included trials, so the three treatment arms were combined into one. ${ }^{59}$ 262

264 first feed, six trials started within 48 hours of birth, one within 72 hours, four within the first 265 week, and in twelve trials therapy started at the "more than 48 hours" time point. 

duration of therapy. ${ }^{52}$ Most studies were classified in the "28 days or more" subgroup for the

269 purposes of analysis by extraction of the actual duration of therapy (when provided) in trials that 270 specified duration as "until discharge".

271

\section{Outcomes}

273 Risk of Bias within Studies

274 See Supplemental Figure 1 for the risk of bias assessment for all included trials. All

275 included trials were randomized (five were judged to have uncertainty around the method of 276 randomization). ${ }^{30,31,34,37,47}$ All of these trials were previously included in the AlFaleh review.

277 Seven trials had a degree of selective reporting one of the trials being from the updated search. ${ }^{66}$ 278 Of the translated trials, randomization was clearly stated, but uncertainty remains about blinding 279 status, allocation concealment, and selective reporting. ${ }^{13-15,18,38}$

280

281

282

283

284 285 286

287 288 289 290 291 292 293

\section{Synthesis of Results}

Two of the "old trials" did not contribute any outcome data to the meta-analysis and were excluded. ${ }^{38,45}$ Data used for the Mohan trial in the previous review appears to be based on personal communication with the authors and could not be corroborated with the published trial. ${ }^{45}$ Li did not report on any usable outcomes. ${ }^{38}$

\section{All infants}

The primary outcome, severe NEC, was significantly reduced in infants who received probiotics compared to placebo with 38 trials (10,520 patients) reporting on this outcome - RR 0.53 [95\% CI 0.42 to 0.66 ] - see Figure 2. The incidence of culture-proven sepsis was not different between the probiotics and control - RR 0.88 [95\% CI 0.77 to 1.00 ) in 31 trials comprising 8707 patients, see Figure 3. The incidence of all-cause mortality was significantly reduced in infants receiving probiotics in 29 trials (9507 patients) - RR 0.79 [95\% CI 0.68 to 
294 0.93] (Figure 4). Other statistically significant findings included shorter duration of

295 hospitalization, increased weight gain (g/day), and reduced time to reach full enteral feeds, all in 296 favor of using probiotics (Table 2).

297

298

299

300

301

302

303

304 305

306

307

308

309

310

311

312

313

314

315

316

317

318

319

320

There was a moderate to large degree of heterogeneity in the results for culture-proven sepsis, duration of hospitalization, duration of parenteral nutrition, and time to achieve full feeds.

\section{VLBW Infants}

The incidence of severe NEC was significantly reduced in VLBW infants who received probiotics compared to placebo including 25 trials (6587 patients) - RR 0.47 [95\% CI 0.36 to

0.61] (Figure 5). The incidence of all-cause mortality was significantly reduced in VLBW infants who received probiotics compared to infants who received placebo in 24 trials (6736 patients) with RR 0.74 [95\% CI 0.61 to 0.90]. Compared to VLBW infants who received placebo, those who received probiotics had a significantly reduced duration of parenteral nutrition (Table 2). There was significant heterogeneity in the outcomes of duration of hospitalization, and time to full feeds.

\section{ELBW infants}

Eight trials reported outcome data on this weight group. ${ }^{30,40-42,46,55,57,66}$ The only trial to enroll infants solely in this weight group was Al-Hosni. ${ }^{30}$ ELBW infants were a pre-specified subgroup in the Jacobs trial. ${ }^{46}$ In the remaining six trials, outcome data for ELBW infants was presented as a post-hoc subgroup analysis. ELBW infants who received probiotics had a significantly shorter duration of hospitalization and reached full enteral feeding sooner compared to infants who received placebo, see Table 2. 
322 (Figure 6), mortality, culture-proven sepsis, any bacterial sepsis and any fungal sepsis. There was 323 significant heterogeneity in the outcomes of culture-proven sepsis and mortality. Other outcomes 324 were only reported in a small number of patients and trials.

325

326

327 328 329 330 331

\section{Initiation of Probiotics}

Severe NEC was significantly reduced in trials where patients were started on probiotics at more than 48 hours of age - RR 0.36 [95\% CI 0.24 to 0.53 ] or in those trials where probiotics were started at the time of the first feed - RR 0.55 [95\% CI 0.41 to 0.75] (Supplemental Figure 2). The incidence of culture-proven sepsis was significantly reduced in the 11 trials in which therapy was started at more than 48 hours of age - RR 0.65 [95\% CI 0.51 to 0.82 ]. A reduction in the incidence of mortality was significant in trials when probiotics were started with the first feed - RR 0.68 [95\% CI 0.51 to 0.90$]$.

\section{Duration of Probiotics}

Subgroups with probiotic duration of at least 14 days or until discharge were statistically significant for a reduced incidence of severe NEC (Supplemental Figure 3). The largest amount of data was in the 28 days or more category, with 28 trials contributing outcome data.

\section{Species of Probiotics}

Outcomes were compared according to the various probiotic species included in the trials. Incidence of severe NEC was significantly reduced in infants receiving a Lactobacillus species (8 trials) - RR 0.61 [95\% CI 0.40 to 0.95], Bifidobacterium species (6 trials) - RR 0.37 [95\%CI 0.14 to 0.97 ], or multispecies (two or more) supplement (18 trials) - RR 0.41 [95\% CI 0.29 to 0.56$]$. Incidence of NEC was not significantly different from control in infants receiving only a Saccharomyces boulardii supplement (2 trials) - RR 0.72 [95\%CI 0.33 to 
346 1.54]. Incidence of culture-proven sepsis was not significantly different from control in infants

347 receiving any probiotic species. Incidence of mortality was significantly reduced only in infants

348 receiving a multispecies supplement (15 trials) — RR 0.66 [95\% CI 0.5 to 0.87].

\section{Breast milk vs. formula feeding}

350 Comparison of the rates of severe NEC between infants fed using breast milk alone and those fed

351 formula alone was not possible due to the lack of studies containing infants fed only formula.

352

353

354

355

\section{Discussion}

This review was done in accordance with current guidelines and strict attention to best

practice of systematic reviews and meta-analysis. ${ }^{17}$ It has added randomized data from over 5000

infants to the previous meta-analyses. Based on high-quality evidence, the use of probiotics in

preterm infants reduces the incidence of severe NEC. The effect size has changed slightly in

comparison to the Cochrane review but the precision of the result remains the same, despite the

360

additional patients. ${ }^{11}$ This may be related to the wide range of probiotic species and regimens

361

included in the analysis and use of the more conservative random effects model for meta-

362

analysis. There was no statistical heterogeneity in the primary outcome, despite the inclusion of

diverse probiotic regimens and species. No other intervention to prevent NEC has demonstrated

this effect size. ${ }^{70-72}$

365

366

367 368

369

370
The concern about bacterial translocation beyond the preterm infant gut should be reflected in the outcome of culture-proven sepsis and/or all-cause mortality. This review found 
371 no increased risk of culture-proven sepsis. No sepsis due to probiotic species was reported

372 among the included trials.

373

374

375 hospitalization. The clinical significance of this reduction is unclear given a mean length of stay 376 in Canadian NICUs of 63.2 days in $2013 . .^{73}$

377

378

The reduction in the duration of parenteral nutrition and time to full enteral feeds is of 379 importance for this patient population, as prolonged parenteral nutrition may be associated with increased hospital stay, mortality, and morbidity. ${ }^{74}$ Recently published evidence-based guidelines echo the need and benefits of achieving full feeds in an efficient manner. ${ }^{75}$

382

In the ELBW infants, the lack of benefit on severe NEC, culture-proven sepsis or

384

385

386

387

388

389

390

391

392

393

394

mortality outcomes was consistent with the previous reviews (despite the addition of four new randomized trials almost doubling the number of infants studied). The direction and magnitude of the point estimates for the effect of probiotics on the incidence of severe NEC and all-cause mortality are consistent with those of the "all infant" sample.

The incidence of NEC and mortality outcomes had little to no heterogeneity which gives substantial confidence in those results. The substantial heterogeneity in sepsis, duration of hospitalization and duration of parenteral nutrition outcomes would suggest caution in interpreting the results. 
395 Timing of probiotic initiation is a clinically important question which was not resolved in the

396 previous reviews. In this review, subgroups for timing mirrored those in the Alfaleh review. ${ }^{11}$

397 The time of initiation of probiotics seemed to have a variable influence on the main three

398 outcomes of severe NEC, culture-proven sepsis, and mortality. When probiotics were started

399 very early (48 hours of age or less) there was no difference in any of the outcomes. There were

400 few trials placed in this category, and therefore the outcomes may lack power to detect a

401 statistical difference. Many trials described initiating probiotic supplementation at the time of

402 first feeding. Without access to individual patient level data, it is unclear how many of the infants

403 categorized into this group could also be included in the 48 hours of age or less category.

404 Consequently, we cannot definitively state that probiotic supplementation should be withheld

405 until at least 48 hours of age or until feeding. Starting probiotics with the initiation of feeds did

406 reduce the incidence of both NEC and mortality and does have some practical advantages in

407 terms of drug administration which make it an opportune time to initiate probiotic prophylaxis.

408 There was a lack of effect on mortality when probiotic supplementation was started after 48

409 hours of age. We can find no explanation for this, especially since the benefit on NEC remained

410 when therapy was started after 48 hours.

411

412 Determining the appropriate duration of therapy is equally important as the timing of

413 initiation. Clinically it seems prudent to continue therapy for as long as there is risk for NEC. A

414 minimum of two weeks of probiotic therapy continued for as long as the patient is judged to be at

415 risk (up to six weeks) can be recommended, since trials in these subgroups showed a lower

416 incidence of NEC.

417 
419 have a protective effect on the incidence of NEC. ${ }^{76,77}$ This review found only one trial in which

420 infants were fed exclusively formula (most other trials included a combination of feeding types),

421 precluding definitive conclusions based on feeding method. The majority of infants were fed a

422 combination of human milk and formula reflecting clinical practice. Future trials may consider

423 having a pre-defined subgroup of breastfed vs. formula fed infants to definitively answer this

424 question.

425 A post hoc subgroup analysis to examine if the effects on severe NEC were consistent

426 based on the underlying background incidence of NEC across the included trials (grouped by less

427 than $5 \%, 5-7 \%$ and more than $7 \%^{5}$ ) was undertaken. Most of the trials were in the low baseline

428 incidence subgroup (18 trials, 4905 patients). The primary outcome remained significant across

429 all groups and reinforces that no matter the institution's incidence of NEC, infants had the same

430 reduction in severe NEC.

431 In many countries, probiotics are not regulated as drugs and products are not subject to

432 the same rigorous quality assurance standards. ${ }^{78}$ Stability and/or species testing was confirmed in 433 nine of the included trials. ${ }^{21,30,36,43,44,65,68,79}$ Hospitals either did their own testing or requested the

434 information from the manufacturer of the probiotic being studied. Institutions are encouraged to

435 conduct their own quality assessment or request quality certificates from the manufacturer of the 436 product being used. ${ }^{80,81}$

\section{Limitations}

438 The limitations to this systematic review were as follows:

439 1. Three of the Chinese language trials ${ }^{16,82,83}$ included in the older review ${ }^{12}$ could not be $440 \quad$ obtained in full text and were not included in this review. 
441

442

443

444

445

446

447

448

449

450

451

452

453

454

455

456

457

458

459

460

461

462

463

\section{Conclusions}

2. No unpublished data was requested from any of the manufacturers of probiotic products assessed in this review.

3. Only one trial in the previous review addressed long term neurodevelopmental outcomes, but this information could not be confirmed. ${ }^{37}$ Akar $2016^{56}$ and the abstract from one of the ProPrems conference presentations ${ }^{84}$ also reports on neurodevelopmental outcomes. If the Kitijama ${ }^{37}$ and ProPrems results were available these could be combined for a summary effect estimate in a future review.

\section{Remaining Uncertainties}

The outcome of fungal sepsis showed a definite benefit with no heterogeneity (Table 2).

Some of the included studies employed antifungal prophylaxis (either systemic or topical) in their infants as per their normal NICU practice. This choice is not the routine practice at all institutions and is not standard practice. ${ }^{85,86}$ The impact of these studies with background antifungal therapy was not explored in sensitivity analyses but could be considered in future reviews for its impact on the outcome of fungal sepsis.

Which probiotic product to use remains uncertain, since the total body of evidence comprises a heterogeneous group of probiotics (individual species and combination products, and regimens). In the previous review, only the Lactobacillus and multispecies supplements were shown to be effective for this outcome. We would recommend a regulatory body-approved product and that quality assessment be requested from the manufacturer to validate the purity of product. The evidence of benefit was clear for Lactobacillus or Bifidobacterium species and multiple species products so any of these would be reasonable choices. 
467

468

469

470

471

472

473

474

475

476

477

478

479

480

481

482

483

484

485

486

487

488

489

490

491

492

493

494

495

496

497

498

499

500

501

502

503

504

clear benefit from the use of probiotics to prevent severe NEC and all-cause mortality, with no increase in culture-proven sepsis. We would recommend using probiotics in premature infants with these characteristics. The evidence for babies of birth weight less than 1000 grams is less clear and we cannot make as strong a recommendation in this class of infants.

\section{Acknowledgements}

We gratefully acknowledge the following LHSC pharmacists for their expertise in translating the Chinese language papers: Emily Chen, Rachel Fu, Vicky Luo, and Boris Tong. We thank Brenda Sampson for her efforts in obtaining articles and the LHSC library staff Valerie Kowalkowski and Juanita Meyer in locating articles.

Table 1: Characteristics of Included Studies

Figure 1: PRISMA Flow Diagram

Figure 2: Severe ( $\geq$ Stage 2 Bell's Criteria) NEC - all infants

Figure 3: Culture-proven sepsis - all infants

Figure 4: Mortality - all infants

Table 2: Additional important findings

Figure 5: Severe NEC - VLBW (Less than $1500 \mathrm{~g}$ ) infants

Figure 6: Severe NEC - ELBW (Less than $1000 \mathrm{~g}$ ) infants

\section{References}

1. Thompson AM, Bizzarro MJ. Necrotizing enterocolitis in newborns: Pathogenesis, prevention and management. Drugs. 2008;68(9):1227-1238. DOI:10.2165/00003495200868090-00004.

2. Morgan JA, Young L, McGuire W. Pathogenesis and prevention of necrotizing enterocolitis. Curr Opin Infect Dis. 2011;24(3):183-189. DOI:10.1097/QCO.0b013e328345d5b5.

3. Sharma R, Hudak ML. A Clinical Perspective of Necrotizing Enterocolitis: Past, Present, and Future. Clin Perinatol. 2013;40(1):27-51. DOI:10.1016/j.clp.2012.12.012.

4. Choi YY. Necrotizing enterocolitis in newborns: update in pathophysiology and newly emerging therapeutic strategies. Korean J Pediatr. 2014;57(12):505. DOI:10.3345/kjp.2014.57.12.505.

5. Henry MCW, Moss RL. Neonatal necrotizing enterocolits. Semin Pediatr Surg. 17(2):98109. DOI:10.1053/j.sempedsurg.2008.02.005.

6. Holman RC, Stoll BJ, Curns AT, Yorita KL, Steiner CA, Schonberger LB. Necrotising 
505 enterocolitis hospitalisations among neonates in the United States. Paediatr Perinat

$506 \quad$ Epidemiol. 2006;20(6):498-506. DOI:10.1111/j.1365-3016.2006.00756.x.

507 7. Sia KL, Gold L, Jacobs S, Cheong J, Opie G, Garland S, Donath S, Hickey L, Boland R,

$508 \quad$ Webster C. Hospital DRG costing and health services use of very pre-term infants from

509 the ProPrems Neuro study across 10 hospitals in Australia and New Zealand. Value Heal.

510 2014;17(7):A518-A519. DOI: 10.1016/j.val.2014.08.1613

511 8. Schanler RJ. Pathology and pathogenesis of necrotizing enterocolitis in newborns. In: Post

512 T, ed. UpToDate. Waltham, Mass.: UpToDate; 2015. www.uptodate.com Accessed:

$513 \quad$ March 16, 2015.

514 9. Terrin G, Scipione A, De Curtis M. Update in pathogenesis and prospective in treatment

515

516

517

10. Morowitz MJ, Poroyko V, Caplan M, Alverdy J LD. Redefining the role of intestinal

518

519

520

521

522

523

524

525

526

527

528

529

530

531

532

533

534 of necrotizing enterocolitis. Biomed Res Int. 2014;2014:543765. DOI:10.1155/2014/543765. microbes in the pathogenesis of necrotizing enterocolitis. Pediatrics. 2010;125(4):777785. DOI:10.1542/peds.2009-3149

11. AlFaleh KAJ. Probiotics for prevention of necrotizing enterocolitis in preterm infants. Cochrane Database Syst Rev. 2014;(4). DOI:10.1002/14651858.

12. Yang Y, Guo Y, Kan Q, Zhou XG, Zhou XY, Li Y. A meta-analysis of probiotics for preventing necrotizing enterocolitis in preterm neonates. Brazilian J Med Biol Res $=$ Rev Bras Pesqui médicas e biológicas / Soc Bras Biofísica . 2014;47(9):804-810. DOI:10.1590/1414-431X20143857.

13. Ke D, Su Z, Li L. [Effects of Bifido supplement for prevention of necrotizing enterocolitis in preterm infants: a randomized controlled trial]. Chinese Pediatr Emerg Med. 2008;12:69-71.

14. Huang B, Yang H, Huang X. [Probiotics supplementation for prevention of necrotizing enterocolitis in very low-birth-weight neonates: a randomized, controlled trial]. $J$ Guangdong Med Coll. 2009;27(1):37-39.

15. Ren B. [Preventive effect of Bifidobacterium tetravaccine tablets in premature infants with necrotizing enterocolitis]. J Pediatr Pharm. 2010;16:24-25. http://en.cnki.com.cn/Article en/CJFDTOTAL-EKYX201002013.htm.

535

536

537

538

539

540

541

542

543

544

16. Di M, Li X. [Effects of Bifidobacterium supplementation for prevention of necrotizing enterocolitis in pre-term infants: a randomized, controlled trial]. Zhong Guo She Qu Yi Shi (Chinese J Commun Dr.) 2010;231:69.

17. Moher D, Liberati A, Tetzlaff J, Altman DG. Preferred reporting items for systematic reviews and meta-analyses: the PRISMA statement. PLoS Med. 2009;339(7):6. http://www.pubmedcentral.nih.gov/articlerender.fcgi?artid=2707599\&tool=pmcentrez\&re ndertype $=$ abstract. DOI: 10.1371/journal.pmed.1000097

18. Hua X-T, Tang J, Mu D-Z. [Effect of oral administration of probiotics on intestinal colonization with drug-resistant bacteria in preterm infants]. Zhongguo Dang Dai Er Ke Za Zhi. 2014;16(6):606-609. http://www.ncbi.nlm.nih.gov/pubmed/24927436. 
545 19. Yang S, Yi H, Gan B. [The clinical application value of endangered preterm infants given

546

547

548

549

550

551

552

553

554

555

556

557

558

559

560

561

562

563

564

565

566

567

568

569

570

571

572

573

574

575

576

577

578

579

580

581

582

583

584 earlier amounts of micro feedings and adding probiotics]. J Pediatr Pharmacydiat Pharm. 2011;17:21-24.

20. Romeo MG, Romeo DM, Trovato L, Oliveri S, Palermo F, Cota F, Betta P. Role of probiotics in the prevention of the enteric colonization by Candida in preterm newborns: incidence of late-onset sepsis and neurological outcome. J Perinatol. 2011;31(1):63-69. http://www.pubmedcentral.nih.gov/articlerender.fcgi?artid=3016918\&tool=pmcentrez\&re ndertype $=$ abstract. Accessed January 12, 2015. DOI: 10.1038/jp.2010.57

21. Underwood MA, Salzman NH, Bennett SH, Barman, M, Mills, DA, Marcobal, A,Tancredi, DJ, Bevins, CL, Sherman, Michael P. A randomized placebo-controlled comparison of 2 prebiotic/probiotic combinations in preterm infants: impact on weight gain, intestinal microbiota, and fecal short-chain fatty acids. J Pediatr Gastroenterol Nutr. 2009;48(2):216-225. http://www.pubmedcentral.nih.gov/articlerender.fcgi?artid=2743418\&tool=pmcentrez\&re $\underline{\text { ndertype }=\text { abstract. }}$ Accessed January 14, 2015. DOI: 10.1097/MPG.0b013e31818de195

22. National Library of Medicine. clinicaltrials.gov. https://clinicaltrials.gov/. Accessed January 14, 2015.

23. World Health Organization International Clinical Trials Registry Platform. http://apps.who.int/trialsearch. Accessed January 14, 2015.

24. American Pediatric Society/Society for Pediatric Research. https://www.apsspr.org/home.asp . Accessed January 15, 2015.

25. European Society of Pediatric Research. http://www.espr.info/. Accessed January 15, 2015.

26. Freelon D. ReCal. http://dfreelon.org/utils/recalfront/recal2/ ). Accessed February 18, 2015.

27. Higgins JP, Deeks J, Altman DG, Cochrane Statistical Methods Group. Special Topics in Statistics. In: Higgins J, Green S, eds. Cochrane Handbook for Systematic Reviews of Interventions. 5.1.0 The Cochrane Collaboration; 2011. www.cochrane-handbook.org.

28. Review Manager (RevMan) [Computer program]. Version 5.3. Copenhagen: The Nordic Cochrane Centre, The Cochrane Collaboration, 2014.

29. Higgins JPT, Thompson SG, Deeks JJ, Altman DG. Measuring inconsistency in metaanalyses. BMJ Br Med J. 2003;327(7414):557-560. DOI:10.1136/bmj.327.7414.557.

30. Al-Hosni M, Duenas M, Hawk M, Stewart LA, Borghese RA, Cahoon M, Atwood L, Howard D, Ferrelli K, Soll, R. Probiotics-supplemented feeding in extremely low-birthweight infants. J Perinatol. 2012;32(4):253-259. DOI:10.1038/jp.2011.51.

31. Bin-Nun A, Bromiker R, Wilschanski M, Kaplan M, Rudenski B, Caplan M, Hammerman C. Oral probiotics prevent necrotizing enterocolitis in very low birth weight neonates. $J$ Pediatr. 2005;147(2):192-196. DOI:10.1016/j.jpeds.2005.03.054.

32. Braga TD, da Silva GAP, de Lira PIC, de Carvalho Lima M. Efficacy of Bifidobacterium breve and Lactobacillus casei oral supplementation on necrotizing enterocolitis in very- 
585

586

587

588

589

590

591

592

593

594

595

596

597

598

599

600

601

602

603

604

605

606

607

608

609

610

611

612

613

614

615

616

617

618

619

620

621

622

623

624

625

low-birth-weight preterm infants: a double-blind, randomized, controlled trial. Am J Clin Nutr. 2011;93(1):81-86. http://ajcn.nutrition.org/content/93/1/81.full. Accessed January 14, 2015.

33. Costalos C, Skouteri V, Gounaris A, Sevastiadou S, Triandafilidou A, Ekonomidou C, Kontaxaki F, Petrochilou V.. Enteral feeding of premature infants with Saccharomyces boulardii. Early Hum Dev. 2003;74(2):89-96. http://www.ncbi.nlm.nih.gov/pubmed/14580749. Accessed January 14, 2015.

34. Dani C, Biadaioli R, Bertini G, Martelli E, Rubaltelli FF. Probiotics feeding in prevention of urinary tract infection, bacterial sepsis and necrotizing enterocolitis in preterm infants. A prospective double-blind study. Biol Neonate. 2002;82(2):103-108. http://www.ncbi.nlm.nih.gov/pubmed/12169832. Accessed January 14, 2015.

35. Demirel G, Erdeve O, Celik IH, Dilmen U. Saccharomyces boulardii for prevention of necrotizing enterocolitis in preterm infants: a randomized, controlled study. Acta Paediatr. 2013;102(12):e560-e565. http://www.ncbi.nlm.nih.gov/pubmed/24028629. Accessed January 14, 2015.

36. Fernandez-Carrocera LA Cabanillas-Ayon M, Gallardo-Sarmiento RB, Garcia-Perez CS, Montano-Rodriguez R, Echaniz-Aviles MO S-HA. Double-blind, randomised clinical assay to evaluate the efficacy of probiotics in preterm newborns weighing less than $1500 \mathrm{~g}$ in the prevention of necrotising enterocolitis. Arch Dis Child Fetal Neonatal Ed. 2013;98(1):F5. DOI: 10.1136/archdischild-2011-300435

37. Kitajima H, Sumida Y, Tanaka R, Yuki N, Takayama H, Fujimura M. Early administration of Bifidobacterium breve to preterm infants: randomised controlled trial. Arch Dis Child Fetal Neonatal Ed. 1997;76(2):F101-F107. http://www.pubmedcentral.nih.gov/articlerender.fcgi?artid=1720633\&tool=pmcentrez\&re ndertype=abstract. Accessed January 14, 2015.

38. Li Y, Shimizu T, Hosaka A, Kaneko N, Ohtsuka Y, Yamashiro Y. Effects of bifidobacterium breve supplementation on intestinal flora of low birth weight infants. Pediatr Int. 2004;46(5):509-515. DOI: 10.1111/j.1442-200x.2004.01953.x

39. Lin H-C, Su B-H, Chen A-C, Lin T-W, Tsai C-H, Yeh TF, Oh W. Oral probiotics reduce the incidence and severity of necrotizing enterocolitis in very low birth weight infants. Pediatrics. 2005;115(1):1-4. DOI: 10.1542/peds.2004-1463

40. Lin H-C, Hsu C-H, Chen H-L, Chung M-Y, Hsu J-F, Lien R-I, Tsao L-Y, Chen C-H, Su, B-H. Oral probiotics prevent necrotizing enterocolitis in very low birth weight preterm infants: a multicenter, randomized, controlled trial. Pediatrics. 2008;122(4):693-700. DOI: $10.1542 /$ peds.2007-3007

41. Manzoni P, Mostert M, Leonessa ML, Priolo C, Farina D, Monetti C, Latino MA, Gomirato G.. Oral supplementation with Lactobacillus casei subspecies rhamnosus prevents enteric colonization by Candida species in preterm neonates: a randomized study. Clin Infect Dis. 2006;42(12):1735-1742. DOI: 10.1086/504324

42. Manzoni P, Rinaldi M, Cattani S, Pugni L, Romeo MG, Messner H, Stolfi I, DecembrinoL, Laforgia N, Vagnarelli F, Memo L, Bordignon L, Saia OS, Maule M, Gallo 
626

627

628

629

630

631

632

633

634

635

636

637

638

639

640

641

642

643

644

645

646

647

648

649

650

651

652

653

654

655

656

657

658

659

660

661

662

663

664

665

666

667
E, Mostert M, Magnani C, Quercia M, Bollani L, Pedicino R, Renzullo L, Betta P, Mosca F, Ferrari F, Magald R, Stronati M, Farina D. . Bovine lactoferrin supplementation for prevention of late-onset sepsis in very low-birth-weight neonates: a randomized trial. JAMA. 2009;302(13):1421-1428. http://www.ncbi.nlm.nih.gov/pubmed/19809023. Accessed December 22, 2014. DOI: 10.1001/jama.2009.1403

43. Mihatsch WA, Vossbeck S, Eikmanns B, Hoegel J, Pohlandt F. Effect of Bifidobacterium lactis on the incidence of nosocomial infections in very-low-birth-weight infants: a randomized controlled trial. Neonatology. 2010;98(2):156-163.

http://www.ncbi.nlm.nih.gov/pubmed/20234140. Accessed January 14, 2015. DOI: $10.1159 / 000280291$

44. Millar MR, Bacon C, Smith SL, Walker V, Hall MA. Enteral feeding of premature infants with Lactobacillus GG. Arch Dis Child. 1993;69(5 Spec No):483-487.

http://www.pubmedcentral.nih.gov/articlerender.fcgi?artid=1029589\&tool=pmcentrez\&re ndertype $=$ abstract. Accessed January 14, 2015.

45. Mohan R, Koebnick C, Schildt J, Schmidt S, Mueller M, Possner M, Radke M, Blaut M. . Effects of Bifidobacterium lactis Bb12 supplementation on intestinal microbiota of preterm infants: a double-blind, placebo-controlled, randomized study. J Clin Microbiol. 2006;44(11):4025-4031.

http://www.pubmedcentral.nih.gov/articlerender.fcgi?artid=1698302\&tool=pmcentrez\&re ndertype $=$ abstract. Accessed December 22, 2014. DOI: 10.1128/JCM.00767-06

46. Jacobs SE, Tobin JM, Opie GF, Donath S, Tabrizi SN, Pirotta M, Morley CJ, Garland SM. Probiotic effects on late-onset sepsis in very preterm infants: a randomized controlled trial. Pediatrics. 2013;132(6):1055-1062. DOI: 10.1542/peds.2013-1339

47. Reuman PD, Duckworth DH, Smith KL, Kagan R, Bucciarelli RL, Ayoub EM. Lack of effect of Lactobacillus on gastrointestinal bacterial colonization in premature infants. Pediatr Infect Dis. 1986;5(6):663-668.

48. Rojas MA, Lozano JM, Rojas MX, Rodriguez VA, Rondon MA, Bastidas JA, Perez, Luis A, Rojas C, Ovalle O,Garcia-Harker, JE, Tamayo ME, Ruiz GC, Ballesteros A, Archila MM, and Arevalo M. Prophylactic probiotics to prevent death and nosocomial infection in preterm infants. Pediatrics. 2012;130(5):e1113-e1120. DOI: 10.1542/peds.2011-3584

49. Rougé C, Piloquet H, Butel M-J, Berger B, Rochat, F, Ferraris L, Des Robert C, Legrand A, de la Cochetière MF, N'Guyen J-M, Vodovar M, Voyer M, Darmaun D, and Rozé, J-C. Oral supplementation with probiotics in very-low-birth-weight preterm infants: a randomized, double-blind, placebo-controlled trial. Am J Clin Nutr. 2009;89(6):18281835. DOI:10.3945/ajen.2008.26919

50. Samanta M, Sarkar M, Ghosh P, Ghosh J kr, Sinha M kr, and Chatterjee S. Prophylactic probiotics for prevention of necrotizing enterocolitis in very low birth weight newborns. $J$ Trop Pediatr. 2009;55(2):128-131. DOI: 10.1093/tropej/fmn091.

51. Sari FN, Dizdar EA, Oguz S, Erdeve O, Uras N, and Dilmen U. Oral probiotics: Lactobacillus sporogenes for prevention of necrotizing enterocolitis in very low-birth weight infants: a randomized, controlled trial. Eur J Clin Nutr. 2011;65(4):434-439. http://www.ncbi.nlm.nih.gov/pubmed/21245887. Accessed January 14, 2015. DOI: 
668

669

670

671

672

673

674

675

676

677

678

679

680

681

682

683

684

685

686

687

688

689

690

691

692

693

694

695

696

697

698

699

700

701

702

703

704

705

706

707

708 10.1038/ejcn.2010.278

52. Stratiki Z, Costalos C, Sevastiadou S, Kastanidou O, Skouroliakou M, Giakoumatou A, and Petrohilou V. The effect of a bifidobacter supplemented bovine milk on intestinal permeability of preterm infants. Early Hum Dev. 2007;83(9):575-579. DOI:10.1016/j.earlhumdev.2006.12.002.

53. Altman D. Practical Statistics for Medical Research. 2nd edition. Boca Raton, FL.: Chapman \& Hall/CRC; 2001.

54. Manzoni P, Meyer M, Stolfi I, Rinaldi M, Cattani S, Pugni L, Romeo MG, Messner H, Decembrino L, Laforgia N, Vagnarelli F, Memo L, Bordignon L, Maule M, Gallo E, Mostert M, Quercia M, Bollani L, Pedicino R, Renzullo L, Betta P, Ferrari F, Alexander T, Magaldi R, Farina D, Mosca F, Stronati M. Bovine lactoferrin supplementation for prevention of necrotizing enterocolitis in very-low-birth-weight neonates: a randomized clinical trial. Early Hum Dev. 2014;90 Suppl 1:S60-S65. DOI: 10.1016/S03783782(14)70020-9

55. Oncel M, Sari FN, Arayici S, Guzoglu N, Erdeve O, Uras N, Oguz S S, Dilmen U.. Lactobacillus Reuteri for the prevention of necrotising enterocolitis in very low birthweight infants: a randomised controlled trial. Arch Dis Child Fetal Neonatal Ed. 2014;99(2):F110-F115. http://fn.bmj.com/content/99/2/F110.full.pdf. DOI: 10.1136/archdischild-2013-304745

56. Akar M, Eras Z, Oncel MY, Arayici S, Guzoglu N, Canpolat FE, Uras N, Oguz SS. Impact of oral probiotics on neurodevelopmental outcomes in preterm infants. J Matern Neonatal Med. 2016:1-5. DOI:10.1080/14767058.2016.1174683.

57. Costeloe K, Hardy P, Juszczak E, Wilks M, Millar MR. Bifidobacterium breve BBG-001 in very preterm infants: a randomised controlled phase 3 trial. Lancet. 2016;387(10019):649-660. http://www.ncbi.nlm.nih.gov/pubmed/26628328. Accessed November 30, 2015. DOI: 10.1016/S0140-6736(15)01027-2

58. Dilli D, Aydin B, Fettah ND, Özyazici E, Beken S, Zenciroglu A, Okumus N, Ozyurt BM, Ipek MS, Akdag A, Turan O, and Bozdag S. The propre-save study: effects of probiotics and prebiotics alone or combined on necrotizing enterocolitis in very low birth weight infants. J Pediatr. 2015;166(3):545-551. DOI:10.1016/j.peds.2014.12.004

59. Dutta S, Ray P, Narang A. Comparison of stool colonization in premature infants by three dose regimes of a probiotic combination: a randomized controlled trial. Am J Perinatol. 2015;32(8):733-740. DOI: 10.1055/s-0034-1395473

60. Sinha A, Gupta SS, Chellani H, Maliye C, Kumari V, Arya S, Garg BS, Gaur SD, Gaind R, Deotale V, Taywade M, Prasad MS, Thavraj V, Mukherjee A and Roy M. Role of probiotics VSL\#3 in prevention of suspected sepsis in low birthweight infants in India: a randomised controlled trial. BMJ Open. 2015;5(7):e006564. DOI:10.1136/bmjopen-2014006564

61. Tewari VV, Dubey SK and Gupta GD. Bacillus clausii for Prevention of Late-onset Sepsis in Preterm Infants: A Randomized Controlled Trial. J Trop Pediatr. 2015;61(5):377-384. DOI:10.1093/tropej/fmv050 
709 62. Fu H, Song Y. [A clinical observation of Bacillus subtilis on neonatal necrotizing

710 enterocolitis]. MCH Care China. 2012;27:2862-2863.

711

712

713

714

715

716

717

718

719

720

721

722

723

724

725

726

727

728

729

730

731

732

733

734

735

736

737

738

739

740

741

742

743

744

745

746

747

748

749

63. Hunter C, Dimaguila MAVT, Gal P, Wimmer JE Jr, Ransom JL, Carlos RQ, McC Smith $M$ and Davanzo CC. Effect of routine probiotic, Lactobacillus reuteri DSM 17938, use on rates of necrotizing enterocolitis in neonates with birthweight $<1000$ grams: a sequential analysis. BMC Pediatr. 2012;12:142.

http://www.pubmedcentral.nih.gov/articlerender.fcgi?artid=3472183\&tool=pmcentrez\&re ndertype=abstract. Accessed January 2, 2015. DOI:10.1186/1471-2431-12-142

64. Li H, Qiao L, Huang L. [Preventive effect of microecological preparation on neonatal necrotizing enterocolitis of 412 premature infants]. J Appl Clin Pediatr. 2011;26:622-623. DOI: 10.3969/j.issn.1003-515X.2011.08.025

65. Patole S, Keil AD, Chang A, Nathan E, Doherty D, Simmer K, Esvaran M, and Conway P. Effect of Bifidobacterium breve M-16V supplementation on fecal bifidobacteria in preterm neonates--a randomised double blind placebo controlled trial. PLoS One. 2014;9(3):e89511. http://www.ncbi.nlm.nih.gov/pmc/articles/PMC3940439/. DOI: 10.1371/journal.pone.0089511

66. Roy A, Chaudhuri J, Sarkar D, Ghosh P, Chakraborty S. Role of enteric supplementation of Probiotics on late-onset sepsis by Candida species in preterm low birth weight neonates: A randomized, double blind, placebo-controlled trial. $N$ Am J Med Sci. 2014;6(1):50-57. DOI:10.4103/1947-2714.125870.

67. Serce O, Benzer D, Gursoy T, Karatekin G, Ovali F. Efficacy of Saccharomyces boulardii on necrotizing enterocolitis or sepsis in very low birth weight infants: a randomised controlled trial. Early Hum Dev. 2013;89(12):1033-1036.

DOI:10.1016/j.earlhumdev.2013.08.013.

68. Van Niekerk E, Kirsten GF, Nell DG, and Blaauw R. Probiotics, feeding tolerance, and growth: a comparison between HIV-exposed and unexposed very low birth weight infants. Nutrition. 2014;30(6):645-653. DOI:10.1016/j.nut.2013.10.024.

69. Van Niekerk E, Nell DG, Blaauw R and Kirsten GF. Human milk oligosaccharides differ between HIV-infected and HIV-uninfected mothers and are related to necrotizing enterocolitis incidence in their preterm very-low-birth-weight infants. $J$ Nutr. 2014;144(8):1227-1233. http://jn.nutrition.org/content/144/8/1227.full.pdf.

70. Foster J, Cole M. Oral immunoglobulin for preventing necrotizing enterocolitis in preterm and low birth-weight neonates. Cochrane database Syst Rev. 2004;(1):CD001816. DOI:10.1002/14651858.CD001816.pub2.

71. Bury RG, Tudehope D. Enteral antibiotics for preventing necrotizing enterocolitis in low birthweight or preterm infants. Cochrane database Syst Rev. 2001;(1):CD000405. DOI:10.1002/14651858.CD000405.

72. Pammi M, Abrams SA. Oral lactoferrin for the prevention of sepsis and necrotizing enterocolitis in preterm infants. Cochrane database Syst Rev. 2015;2:CD007137. DOI:10.1002/14651858.CD007137.pub4.

73. The Canadian Neonatal Network. The Canadian Neonatal Network Annual Report 2013. 
750

751

752

753

754

755

756

757

758

759

760

761

762

763

764

765

766

767

768

769

770

771

772

773

774

775

776

777

778

779

780

781

782

783

784

785

786

787

788

789

Toronto, Ontario, Canada; 2011.

http://www.canadianneonatalnetwork.org/Portal/LinkClick.aspx?fileticket=lreR0871sjA= \&tabid=39.

74. Flidel-Rimon O, Friedman S, Lev E, Juster-Reicher A, Amitay M, Shinwell ES. Early enteral feeding and nosocomial sepsis in very low birthweight infants. Arch Dis Child Fetal Neonatal Ed . 2004;89 (4 ):F289-F292. DOI:10.1136/adc.2002.021923.

75. Dutta S, Singh B, Chessell L, Wilson J, Janes M, McDonald K, Shahid S, Gardner VA, Hjartarson A, Purcha M, Watson J, De Boer C, Gaal B, and Fusch C. Guidelines for Feeding Very Low Birth Weight Infants. Nutrients. 2015;7(1):423-442.

DOI:10.3390/nu7010423.

76. Sullivan S, Schanler RJ, Kim JH, Patel AL, Trawöger R, Kiechl-Kohlendorfer U, Chan GM, Blanco CL, Abrams S, Cotten CM, Laroia N, Ehrenkranz RA, Dudell G, Cristofalo EA, Meier P, Lee ML, Rechtman DJ, and Lucas A. An exclusively human milk-based diet is associated with a lower rate of necrotizing enterocolitis than a diet of human milk and bovine milk-based products. J Pediatr. 2010;156(4):562-567.e1.

DOI:10.1016/j.jpeds.2009.10.040.

77. Meinzen-Derr J, Poindexter B, Wrage L, Morrow AL, Stoll B, Donovan EF. Role of human milk in extremely low birth weight infants' risk of necrotizing enterocolitis or death. J Perinatol. 2009;29(1):57-62. DOI:10.1038/jp.2008.117.

78. Venugopalan V, Shriner KA, Wong-Beringer A. Regulatory oversight and safety of probiotic use. Emerg Infect Dis. 2010;16(11):1661-1665. http://www.pubmedcentral.nih.gov/articlerender.fcgi? artid=3294522\&tool=pmcentrez\&re ndertype=abstract. Accessed March 31, 2015.

79. Van Niekerk E, Nel DG, Blaauw R, Kirsten GF. Probiotics Reduce Necrotizing Enterocolitis Severity in HIV-exposed Premature Infants. J Trop Pediatr. February 2015. DOI:10.1093/tropej/fmv004.

80. Chan L-N. Probiotics for Neonates: Safety for Prime Time Questioned without Regulatory Changes. J Pediatr. 166(2):502. DOI:10.1016/j.jpeds.2014.10.041.

81. Barrington KJ, Janvier A. Reply. J Pediatr. 166(2):502-503. DOI:10.1016/j.jpeds.2014.10.063.

82. Deng J, Chen K. [Early minimal feeding combined with probiotics to prevent necrotizing enterocolitis in preterm infant]. Chinese J Mod Drug App. 2010;4:13-14.

83. Zhou N. [The observation of effect of probiotics in the prevention of neonatal necrotizing enterocolitis]. Chinese J Ethnomed Ethnopharm. 2012;21:81.

84. Jacobs SE, Leah Hickey, Susan Donath, Gillian Opie, Peter Anderson, Suzanne Garland JC. Probiotics and Neurodevelopment in Very Preterm Infants: Follow-Up of a Randomised Controlled Trial. In: Pediatric Academic Societies' Annual Meeting. ; 2016. https:/www.pas-meeting.org/.

85. Benjamin DK Jr, Hudak ML, Duara S, Randolph DA, Bidegain M, Mundakel GT, Natarajan G, Burchfield DJ, White RD, Shattuck KE, Neu N, Bendel CM, Kim MR, Finer 
790

791

792

793

794

795

796

797

NN, Stewart DL, Arrieta AC, Wade KC, Kaufman DA, Manzoni P, Prather KO, Testoni D, Berezny KY, Smith PB; Fluconazole Prophylaxis Study Team. Effect of fluconazole prophylaxis on candidiasis and mortality in premature infants: a randomized clinical trial. JAMA. 2014;311(17):1742-1749. DOI:10.1001/jama.2014.2624.

86. Austin N, Darlow BA, McGuire W. Prophylactic oral/topical non-absorbed antifungal agents to prevent invasive fungal infection in very low birth weight infants. Cochrane database Syst Rev. 2013;3:CD003478. DOI:10.1002/14651858.CD003478.pub4. 


\section{Table $\mathbf{1}$ (on next page)}

Characteristics of included trials 
Table 1 - Characteristics of Included Studies

\begin{tabular}{|c|c|c|c|c|c|c|c|c|c|}
\hline \multirow[b]{2}{*}{ Identifier } & \multicolumn{3}{|c|}{ Inclusion Criteria } & \multirow{2}{*}{$\begin{array}{l}\text { Number } \\
\text { randomized in each } \\
\text { group } \\
\end{array}$} & \multirow[b]{2}{*}{ Probiotic Species (Brand names) } & \multirow[b]{2}{*}{ Total Dose (cfu/day) } & \multirow[b]{2}{*}{ Initiationa } & \multirow[b]{2}{*}{ Duration $^{\mathrm{b}}$} & \multirow[b]{2}{*}{$\begin{array}{l}\text { Feeding }(B, \\
P F, F \text {, Mixed }\end{array}$} \\
\hline & $\begin{array}{l}\text { Gestational } \\
\text { Age }\end{array}$ & Birth weight & $\begin{array}{c}\begin{array}{c}\text { Other inclusion } \\
\text { criteria }\end{array} \\
\end{array}$ & & & & & & \\
\hline Al-Hosni $2012^{30}$ & "preterm" & $501-1000 \mathrm{~g}$ & $\begin{array}{l}14 \text { days of age or } \\
\text { less at the time of } \\
\text { initiation of feeds }\end{array}$ & $\begin{array}{l}\text { Probiotic: } 50 \\
\text { Control: } 51\end{array}$ & $\begin{array}{l}\text { Lactobacillus rhamnosus GG LGG - } \\
0.5 \text { billion (Culturelle } \AA \text { ) } \\
\text { Bifidobacterium infantis }-0.5 \text { billion } \\
\text { (Align } \AA \text { ) }\end{array}$ & 1 billion & $\begin{array}{l}\text { At the time of } \\
\text { first feeding }\end{array}$ & 28 days or more & Not stated \\
\hline Bin-Nun $2005^{31}$ & "preterm" & $\begin{array}{l}\text { Less than } \\
1500 \mathrm{~g}\end{array}$ & None & $\begin{array}{l}\text { Probiotic: } 72 \\
\text { Control: } 73\end{array}$ & $\begin{array}{l}\text { B infantis - } 0.35 \text { billion } \\
\text { Bifidobacteria bifidus }-0.35 \text { billion } \\
\text { Streptococcus thermophilus }-0.35 \\
\text { billion (ABC Dophilus } ® \text { ) }\end{array}$ & 1.05 billion & $\begin{array}{l}\text { At the time of } \\
\text { first feeding }\end{array}$ & 28 days or more & Mixed \\
\hline Braga $2011^{32}$ & None & $750-1499 \mathrm{~g}$ & $\begin{array}{l}\text { Born locally and } \\
\text { admitted to NICU }\end{array}$ & $\begin{array}{l}\text { Probiotic: } 119 \\
\text { Control: } 112\end{array}$ & $\begin{array}{l}\text { Lactobacillus casei }-0.002 \text { to } 2 \text { billion } \\
\text { Bifidobacterium breve }-0.005 \text { to } 5 \\
\text { billion(Yakult LB } ₫ \text { - Sao Paulo, Brazil) }\end{array}$ & 0.035 to 3.5 billion & 48 hours or less & $\begin{array}{l}\text { Planned for } 30 \mathrm{~d} \\
\text { of life, diagnosis } \\
\text { of NEC, } \\
\text { discharge from } \\
\text { hospital or death, } \\
\text { whichever } \\
\text { occurred first } \\
\end{array}$ & Mixed \\
\hline Costalos $2003^{33}$ & 28-32 weeks & None & None & $\begin{array}{l}\text { Probiotic: } 51 \\
\text { Control: } 36 \\
\end{array}$ & Saccharomyces boulardii & 2 billion & $\begin{array}{l}\text { At the time of } \\
\text { first feeding }\end{array}$ & 28 days or more & Mixed \\
\hline Dani $2002^{34}$ & $\begin{array}{l}\text { Less than } 33 \\
\text { weeks }\end{array}$ & $\begin{array}{l}\text { Less than } \\
1500 \mathrm{~g}\end{array}$ & None & $\begin{array}{l}\text { Probiotic: } 295 \\
\text { Control: } 290\end{array}$ & L rhamnosus GG (Dicoflor $®)$ & 6 billion & $\begin{array}{l}\text { At the time of } \\
\text { first feeding }\end{array}$ & 28 days or more & Mixed \\
\hline Demirel $2013^{35}$ & $\begin{array}{l}\text { Less than } 32 \\
\text { weeks }\end{array}$ & $1500 \mathrm{~g}$ or less & $\begin{array}{l}\text { Survival to start } \\
\text { enteral feeding }\end{array}$ & $\begin{array}{l}\text { Probiotic: } 135 \\
\text { Control: } 136\end{array}$ & S boulardii (Reflor $囚)$ & 5 billion & $\begin{array}{l}\text { At the time of } \\
\text { first feeding }\end{array}$ & 28 days or more & Mixed \\
\hline Dilli $2015^{58 c}$ & $\begin{array}{l}\text { Less than } 32 \\
\text { weeks }\end{array}$ & $\begin{array}{l}\text { Less than } \\
1500 \mathrm{~g}\end{array}$ & $\begin{array}{l}7 \text { days of age or } \\
\text { less at the time of } \\
\text { initiation of feeds }\end{array}$ & $\begin{array}{l}\text { Probiotic: } 100 \\
\text { Synbiotic: } 100 \\
\text { Prebiotic: } 100 \\
\text { Control: } 100 \\
\end{array}$ & $\begin{array}{l}\text { B. lactis } 5 \text { billion } \\
\text { B. lactis } 5 \text { billion + inulin } \\
\text { Inulin } 900 \mathrm{mg} \text { (Maflor } \circledast)\end{array}$ & 5 billion & $\begin{array}{l}\text { More than } 48 \\
\text { hours }\end{array}$ & 28 days or more & Mixed \\
\hline Dutta $2015^{59}$ & $\begin{array}{l}27-33 \\
\text { weeks }\end{array}$ & None & $\begin{array}{l}\text { Aged less than } 96 \\
\text { hrs, likely to } \\
\text { remain in hospital } \\
\text { or reside within } 30 \\
\text { km for } 28 \text { days, } \\
\text { tolerating } 15 \\
\mathrm{~mL} / \mathrm{kg} / \mathrm{d} \text { of milk } \\
\text { feeds } \\
\end{array}$ & $\begin{array}{l}\text { High-dose long } \\
\text { course: } 38 \\
\text { High-dose short } \\
\text { course: } 38 \\
\text { Low dose, long } \\
\text { course: } 38 \\
\text { Control: } 35\end{array}$ & $\begin{array}{l}\text { Low Dose: L. acidophilus ( } 662.5 \\
\text { million), L. rhamnosus ( } 362.5 \text { million), } \\
\text { B. longum ( } 87.5 \text { million), S. boulardii } \\
\text { (137.5 million); High Dose: L. } \\
\text { acidophilus ( } 5.3 \text { billion), L. rhamnosus } \\
\text { ( } 2.9 \text { billion), B. longum ( } 700 \text { million), } \\
\text { S. boulardii (1.1 billion) }\end{array}$ & $\begin{array}{l}\text { Low dose: } 2 \text { billion } \\
\text { High dose: } 20 \text { billion }\end{array}$ & $\begin{array}{l}\text { Within the first } \\
\text { week }\end{array}$ & 28 days or more & Mixed \\
\hline $\begin{array}{l}\text { Fernández- } \\
\text { Carrocera } 2013^{36}\end{array}$ & "preterm" & $\begin{array}{l}\text { Less than } \\
1500 \mathrm{~g}\end{array}$ & None & $\begin{array}{l}\text { Probiotic: } 75 \\
\text { Control: } 75 \\
\end{array}$ & $\begin{array}{l}\text { Lactobacillus acidophilus - } 1 \text { billion } \\
\text { L rhamnosus }-0.44 \text { billion }\end{array}$ & 2.65 billion & $\begin{array}{l}\text { At the time of } \\
\text { first feeding }\end{array}$ & 28 days or more & Mixed \\
\hline
\end{tabular}




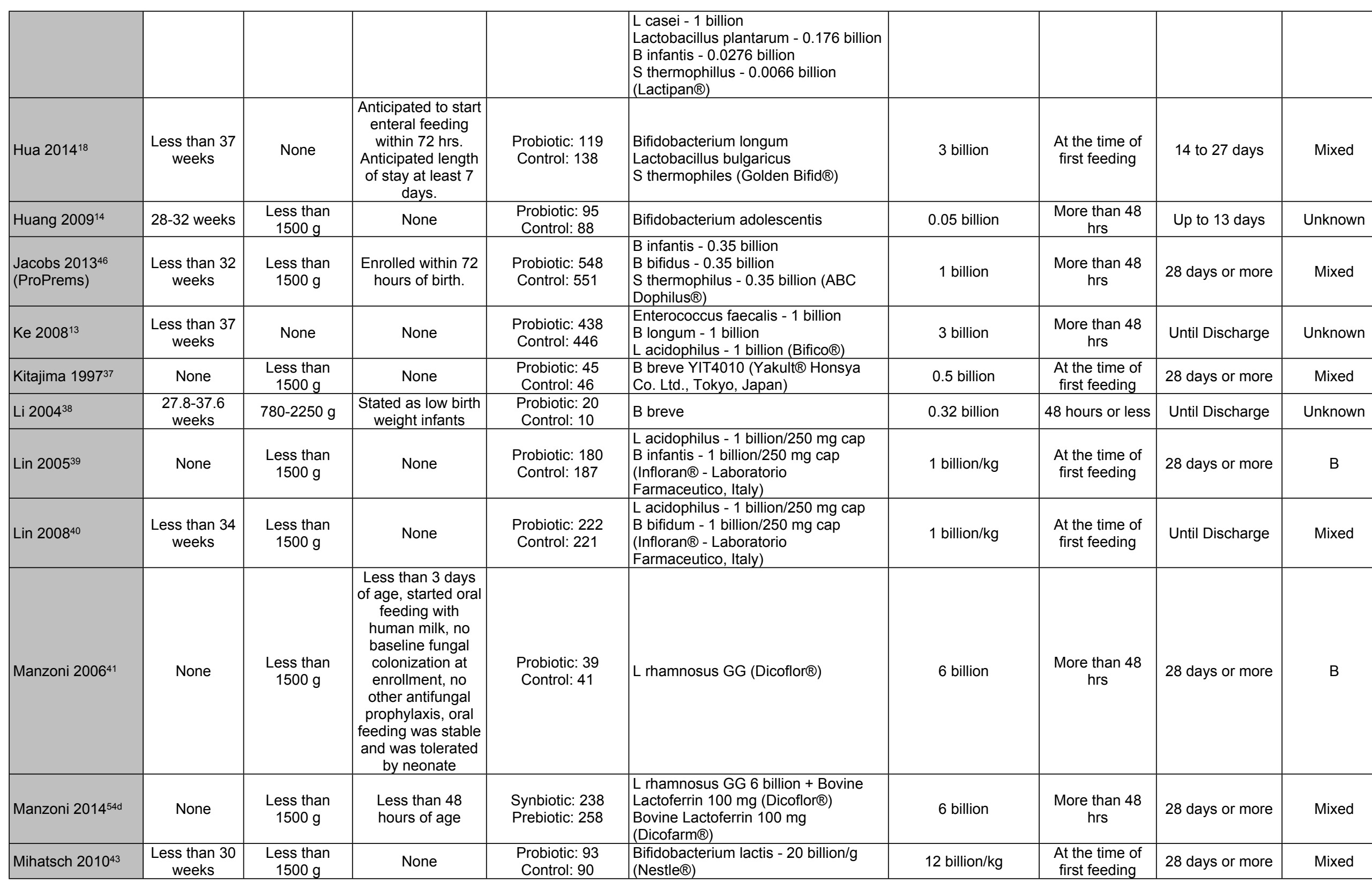




\begin{tabular}{|c|c|c|c|c|c|c|c|c|c|}
\hline Millar $1993^{44}$ & $\begin{array}{c}33 \text { weeks or } \\
\text { less }\end{array}$ & None & None & $\begin{array}{l}\text { Probiotic: } 10 \\
\text { Control: } 10\end{array}$ & $\begin{array}{l}\text { L rhamnosus GG (Valio Finnish Co- } \\
\text { operative Dairies Association } \AA \text { ) }\end{array}$ & 0.2 billion & $\begin{array}{l}\text { At the time of } \\
\text { first feeding }\end{array}$ & 14 days & Mixed \\
\hline Mohan $2006^{45}$ & $\begin{array}{l}\text { Less than } 37 \\
\text { weeks }\end{array}$ & None & None & $\begin{array}{l}\text { Probiotic: } 37 \\
\text { Control: } 32 \\
\end{array}$ & $\begin{array}{l}\text { B lactis Bb12 - } 2 \text { billion/g (Nestle FM } \\
2000 A 囚)\end{array}$ & 4.8 billion & 48 hours or less & 14 to 27 days & $\begin{array}{c}\text { F/B status no } \\
\text { stated }\end{array}$ \\
\hline Oncel $2014^{55}$ & $\begin{array}{c}32 \text { weeks or } \\
\text { less }\end{array}$ & $1500 \mathrm{~g}$ or less & None & $\begin{array}{l}\text { Probiotic: } 200 \\
\text { Control: } 200 \\
\end{array}$ & $\begin{array}{l}\begin{array}{l}\text { Lactobacillus reuteri DSM } 17938 \text { in oil } \\
\left(\text { Biogaia }{ }^{\circledR}\right)\end{array} \\
\end{array}$ & 0.1 billion & $\begin{array}{l}\text { At the time of } \\
\text { first feeding }\end{array}$ & 28 days or more & Mixed \\
\hline Patole 201465 & $\begin{array}{l}\text { Less than } 33 \\
\text { weeks }\end{array}$ & $\begin{array}{l}\text { Less than } \\
1500 \mathrm{~g}\end{array}$ & $\begin{array}{l}\text { Ready to } \\
\text { commence or on } \\
\text { enteral feeds for } \\
<12 \text { hours } \\
\end{array}$ & $\begin{array}{l}\text { Probiotic: } 77 \\
\text { Control: } 76\end{array}$ & $\begin{array}{l}\text { B breve M-16V (Morinaga Milk } \\
\text { Industry Co, Ltd®, Tokyo, Japan) }\end{array}$ & 3 billion & $\begin{array}{l}\text { At the time of } \\
\text { first feeding }\end{array}$ & 28 days or more & Mixed \\
\hline Ren $2010^{15}$ & 28-33 weeks & $1000-1800 \mathrm{~g}$ & None & $\begin{array}{l}\text { Probiotic: } 80 \\
\text { Control: } 70\end{array}$ & $\begin{array}{l}\text { B infantis }-0.005 \text { billion } \\
\text { L acidophilus }-0.005 \text { billion } \\
\text { E faecalis }-0.005 \text { billion } \\
\text { Bacillus cereus }-0.0005 \text { billion } \\
\text { (Bifidobacterium tetravaccine) }\end{array}$ & 0.016 billion & $\begin{array}{l}\text { At the time of } \\
\text { first feeding }\end{array}$ & Up to 13 days & Unknown \\
\hline Reuman $1986^{47}$ & "preterm" & $\begin{array}{l}\text { Less than } \\
2000 \mathrm{~g}\end{array}$ & $\begin{array}{c}\text { Greater than } 24 \\
\text { hrs, but less than } \\
72 \text { hrs old }\end{array}$ & $\begin{array}{l}\text { Probiotic: } 15 \\
\text { Control: } 15\end{array}$ & $\begin{array}{l}\text { L acidophilus (Chris Hansen } \\
\text { Laboratory, Inc. } 囚 \text {, Milwaukee, WI) }\end{array}$ & 0.018 billion & Within 72 hrs & 28 days or more & Mixed \\
\hline Rojas $2012^{48}$ & "preterm" & $2000 \mathrm{~g}$ or less & None & $\begin{array}{l}\text { Probiotic: } 372 \\
\text { Control: } 378 \\
\end{array}$ & L reuteri DSM 17938 in oil (Biogaia $\left.{ }^{\circledR}\right)$ & 0.1 billion & 48 hours or less & 14 to 27 days & Mixed \\
\hline Romeo $2011^{20 e}$ & $\begin{array}{l}\text { Less than } 37 \\
\text { weeks }\end{array}$ & $\begin{array}{l}\text { Less than } \\
2500 \mathrm{~g}\end{array}$ & $\begin{array}{l}\text { - age }<2 \text { wks } \\
\text {-feeds within } 72 \\
\text { hrs }\end{array}$ & $\begin{array}{c}\text { Probiotic (L reuteri): } \\
83 \\
\text { Probiotic }(\mathrm{L} \\
\text { rhamnosus): } 83 \\
\text { Control: } 83\end{array}$ & $\begin{array}{l}\text { L reuteri DSM } 17938 \text { in oil (Biogaia } 囚) \\
\left.\text { L rhamnosus GG (Dicoflor }{ }^{\circledR}\right)\end{array}$ & $\begin{array}{l}0.1 \text { billion } L \text { reuteri or } \\
6 \text { billion } L \text { rhamnosus }\end{array}$ & $\begin{array}{l}\text { More than } 48 \\
\text { hrs }\end{array}$ & 14 to 27 days & Mixed \\
\hline Rougé 200949 & $\begin{array}{l}\text { Less than } 32 \\
\text { week }\end{array}$ & $\begin{array}{l}\text { Less than } \\
1500 \mathrm{~g}\end{array}$ & $\begin{array}{c}\text { postnatal age }</= \\
2 \text { week, the } \\
\text { absence of any } \\
\text { disease other than } \\
\text { those linked to } \\
\text { prematurity and } \\
\text { the start of enteral } \\
\text { feeding }\end{array}$ & $\begin{array}{l}\text { Probiotic: } 43 \\
\text { Placebo: } 49\end{array}$ & $\begin{array}{l}\text { L rhamnosus GG - } 0.1 \text { billion (Valio, } \\
\text { Ltd®) } \\
\text { B longum BB536 - } 0.1 \text { billion } \\
\text { (Morinaga Milk Industry Co, Ltd®, } \\
\text { Tokyo, Japan) }\end{array}$ & 0.8 billion & $\begin{array}{l}\text { At the time of } \\
\text { first feeding }\end{array}$ & 28 days or more & B \\
\hline Roy $2014^{66}$ & $\begin{array}{l}\text { Less than } 37 \\
\text { weeks }\end{array}$ & $\begin{array}{l}\text { Less than } \\
2500 \mathrm{~g}\end{array}$ & $\begin{array}{c}\text { Stable oral feeding } \\
\text { within } 72 \mathrm{~h} \text { of birth, } \\
\text { adequate renal } \\
\text { and liver function, } \\
\text { a postnatal age < } \\
2 \text { week } \\
\end{array}$ & $\begin{array}{l}\text { Probiotic: } 56 \\
\text { Control: } 56\end{array}$ & $\begin{array}{l}\text { L acidophilus }-1.25 \text { billion/g } \\
\text { B longum }-0.125 \text { billion/g } \\
\text { B bifidum }-0.125 \text { billion/g } \\
\text { B lactis }-1 \text { billion/g } \\
\text { (Prowel } \AA \text { ) }\end{array}$ & 1.25 billion & $\begin{array}{l}\text { More than } 48 \\
\text { hrs }\end{array}$ & 28 days or more & B \\
\hline Samanta 200950 & $\begin{array}{l}\text { Less than } 32 \\
\text { weeks }\end{array}$ & $\begin{array}{l}\text { Less than } \\
1500 \mathrm{~g}\end{array}$ & $\begin{array}{c}\text { Started feed } \\
\text { enterally and } \\
\text { survived beyond } \\
48 \mathrm{~h} \text { of life } \\
\end{array}$ & $\begin{array}{c}\text { Probiotic: } 91 \\
\text { Control: } 95\end{array}$ & $\begin{array}{l}\text { B infantis }-2.5 \text { billion } \\
\text { B bifidum }-2.5 \text { billion } \\
\text { B longum }-2.5 \text { billion } \\
\text { L acidophilus }-2.5 \text { billion } \\
\end{array}$ & 20 billion & $\begin{array}{c}\text { More than } 48 \\
\text { hrs }\end{array}$ & 14 to 27 days & B \\
\hline
\end{tabular}




\begin{tabular}{|c|c|c|c|c|c|c|c|c|c|}
\hline Serce $2013^{67}$ & $\begin{array}{c}32 \text { weeks or } \\
\text { less }\end{array}$ & $1500 \mathrm{~g}$ or less & $\begin{array}{l}\text { Survival to feed } \\
\text { enterally }\end{array}$ & $\begin{array}{l}\text { Probiotic: } 104 \\
\text { Control: } 104\end{array}$ & S boulardii (Reflor $\AA)$ & 1 billion & $\begin{array}{l}\text { At the time of } \\
\text { first feeding }\end{array}$ & 28 days or more & Mixed \\
\hline Sinha $2015^{60}$ & None & $1500-2500 \mathrm{~g}$ & $\begin{array}{l}\text { Residing within } 20- \\
25 \mathrm{~km} \text { of hospital } \\
\text { and not planning } \\
\text { to shift residences } \\
\text { for at least the } \\
\text { next } 2 \text { months }\end{array}$ & $\begin{array}{l}\text { Probiotic: } 668 \\
\text { Control: } 672\end{array}$ & $\begin{array}{l}\text { VSL\#3®: Streptococcus } \\
\text { thermophilus, Bifidobacterium breve, } \\
\text { Bifidobacterium longum, } \\
\text { Bifidobacterium infantis, Lactobacillus } \\
\text { acidophilus, Lactobacillus plantarum, } \\
\text { Lactobacillus paracasei and } \\
\text { Lactobacillus delbrueckii spp } \\
\text { bulgaricus. }\end{array}$ & 10 billion & $\begin{array}{l}\text { Within the first } \\
\text { week }\end{array}$ & 28 days or more & B \\
\hline Stratiki $2007^{52}$ & $\begin{array}{l}27 \text { to } 37 \\
\text { weeks }\end{array}$ & None & formula fed & $\begin{array}{c}\text { Probiotic: } 41 \\
\text { Control: } 34\end{array}$ & B lactis (Prenan Nestlé $®$ ) & 0.2 billion $/ \mathrm{kg}$ & 48 hours or less & Not stated & $\mathrm{PF}$ \\
\hline Tewari $2015^{61}$ & $\begin{array}{l}27-30 \text { weeks } \\
+6 \text { days and } \\
31-33 \text { weeks } \\
+6 \text { days }\end{array}$ & None & None & $\begin{array}{c}\text { Probiotic:123 } \\
\text { Control:121 }\end{array}$ & $\begin{array}{l}\text { Bacillus clausii } 2 \text { billion } \\
\left.\text { (Enterogermina }{ }^{\circledR}\right)\end{array}$ & 6 billion & $\begin{array}{c}\text { More than } 48 \\
\text { hrs }\end{array}$ & 28 days or more & B \\
\hline $\begin{array}{l}\text { Underwood } \\
2009^{21 e}\end{array}$ & $\begin{array}{l}\text { Less than } 35 \\
\text { weeks }\end{array}$ & 750 to $2000 \mathrm{~g}$ & $\begin{array}{l}\text { Younger than } 7 \\
\text { days old }\end{array}$ & $\begin{array}{c}\text { Probiotic: } \\
\text { (Culturelle): } 30 \\
\text { Probiotic: } \\
\text { (ProBioPlus): } 31 \\
\text { Control: } 29\end{array}$ & $\begin{array}{l}\text { L rhamnosus GG - } 10 \text { billion/cap } \\
\text { (ProBioPlus DDS) } \\
\text { B infantis - } 10 \text { billion/cap } \\
\text { B bifidum - } 10 \text { billion/cap } \\
\text { B longum - } 10 \text { billion/cap } \\
\text { L acidophilus - } 10 \text { billion/cap } \\
\text { (Culturelle } 囚 \text { ) }\end{array}$ & $\begin{array}{c}0.5 \text { billion Culturelle } \\
\text { or } \\
2 \text { billion ProBioPlus }\end{array}$ & $\begin{array}{l}\text { Within the First } \\
\text { Week }\end{array}$ & 28 days or more & Mixed \\
\hline $\begin{array}{l}\text { Van Niekerk } \\
2014^{68,69 f}\end{array}$ & $\begin{array}{c}\text { Less than } 34 \\
\text { weeks }\end{array}$ & 500 to $1250 \mathrm{~g}$ & $\begin{array}{l}\text { HIV exposed and } \\
\text { unexposed born to } \\
\text { HIV positive or } \\
\text { negative mothers } \\
\text { who agreed to } \\
\text { breastfeed }\end{array}$ & $\begin{array}{l}\text { Probiotic: } 91 \\
\text { Control: } 93\end{array}$ & $\begin{array}{l}\text { L rhamnosus GG }-0.35 \text { billion } \\
\text { B infantis - } 0.35 \text { billion } \\
\text { (Pro-B2®) }\end{array}$ & 0.7 billion & $\begin{array}{l}\text { At the time of } \\
\text { first feeding }\end{array}$ & 28 days or more & B \\
\hline Yang $2011^{19}$ & $\begin{array}{l}\text { Less than } 37 \\
\text { weeks }\end{array}$ & $\begin{array}{l}<1500 \text { to } \\
>2500 \mathrm{~g}\end{array}$ & $\begin{array}{c}2 \text { week length of } \\
\text { stay and admitted } \\
\text { within } 24 \text { hours }\end{array}$ & $\begin{array}{l}\text { Probiotic: } 31 \\
\text { Control: } 31\end{array}$ & $\begin{array}{l}\text { B longum }-0.005 \text { billion } \\
\text { L acidophilus }-0.005 \text { billion } \\
\text { E faecalis }-0.005 \text { billion }\end{array}$ & 0.03 billion & $\begin{array}{l}\text { At the time of } \\
\text { first feeding }\end{array}$ & Up to 13 days & Unknown \\
\hline
\end{tabular}

alnitiation of probiotic therapy was categorized to fit the defined subgroups for data analysis. ${ }^{b}$ Duration of probiotic therapy

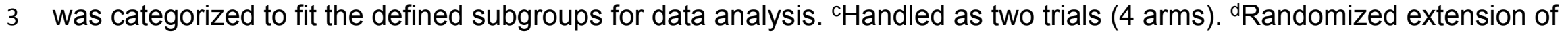
4 the 2009 publication. 39 eHandled as two trials to account for the 3 arms in the trial.

5 Included two randomized clinical studies, one of HIV-exposed and one of HIV-unexposed preterm infants which were 6 analyzed as two trials.

7 B: breastfeeding only, PF: preterm formula, F: formula, Mixed: mixed feeding types 
Table 2 (on next page)

Table 2 - Additional Important Findings 
1 Table 2 - Additional important findings

2

\begin{tabular}{|c|c|c|c|c|}
\hline Outcome & $\begin{array}{l}\text { Number of } \\
\text { studies / } \\
\text { participants }\end{array}$ & Effect size & $95 \% \mathrm{Cl}$ & $\mathrm{I}^{2}(\%)$ \\
\hline \multicolumn{5}{|c|}{ All Infants } \\
\hline Bacterial sepsis & $9 / 2212$ & RR 0.86 & 0.62 to 1.18 & 52 \\
\hline Fungal sepsis & 12 / 3756 & RR 0.67 & 0.43 to 1.06 & 10 \\
\hline $\begin{array}{l}\text { Duration of } \\
\text { hospitalization (days) }\end{array}$ & $16 / 4915$ & MD -3.2 & -5.5 to -0.9 & 84 \\
\hline Weight gain (g/day) & $3 / 314$ & $\mathrm{MD}+1.7$ & 1.0 to 2.3 & 0 \\
\hline $\begin{array}{l}\text { Time to achieve full } \\
\text { feeds (days) }\end{array}$ & $17 / 4448$ & MD -1.2 & -2.2 to -0.1 & 93 \\
\hline \multicolumn{5}{|c|}{ VLBW infants } \\
\hline Culture-proven sepsis & 24 / 6616 & RR 0.93 & 0.82 to 1.05 & 15 \\
\hline $\begin{array}{l}\text { Duration parenteral } \\
\text { nutrition (days) }\end{array}$ & $4 / 1210$ & MD -1.2 & -2.3 to -0.02 & 0 \\
\hline \multicolumn{5}{|c|}{ ELBW infants } \\
\hline Culture-proven sepsis & $6 / 1703$ & RR 0.95 & 0.72 to 1.26 & 41 \\
\hline Mortality & $4 / 1122$ & RR 0.92 & 0.046 to 1.83 & 47 \\
\hline $\begin{array}{l}\text { Duration of } \\
\text { hospitalization (days) }\end{array}$ & $2 / 218$ & MD -6.4 & -12.6 to -0.1 & 0 \\
\hline $\begin{array}{l}\text { Time to achieve full } \\
\text { feeds (days) }\end{array}$ & $2 / 218$ & MD -1.8 & -2.9 to -0.7 & 0 \\
\hline
\end{tabular}

3 MD - mean difference, RR - risk ratio, $\mathrm{Cl}$ - confidence interval, NEC - necrotizing enterocolitis,

4 VLBW - very low birth weight (<1500 g), ELBW - extremely low birth weight $(<1000 \mathrm{~g})$ 
Figure 1 (on next page)

PRISMA Flow Diagram 
Figure 2 (on next page)

Forest plot showing the effect of probiotics on severe NEC in all infants 


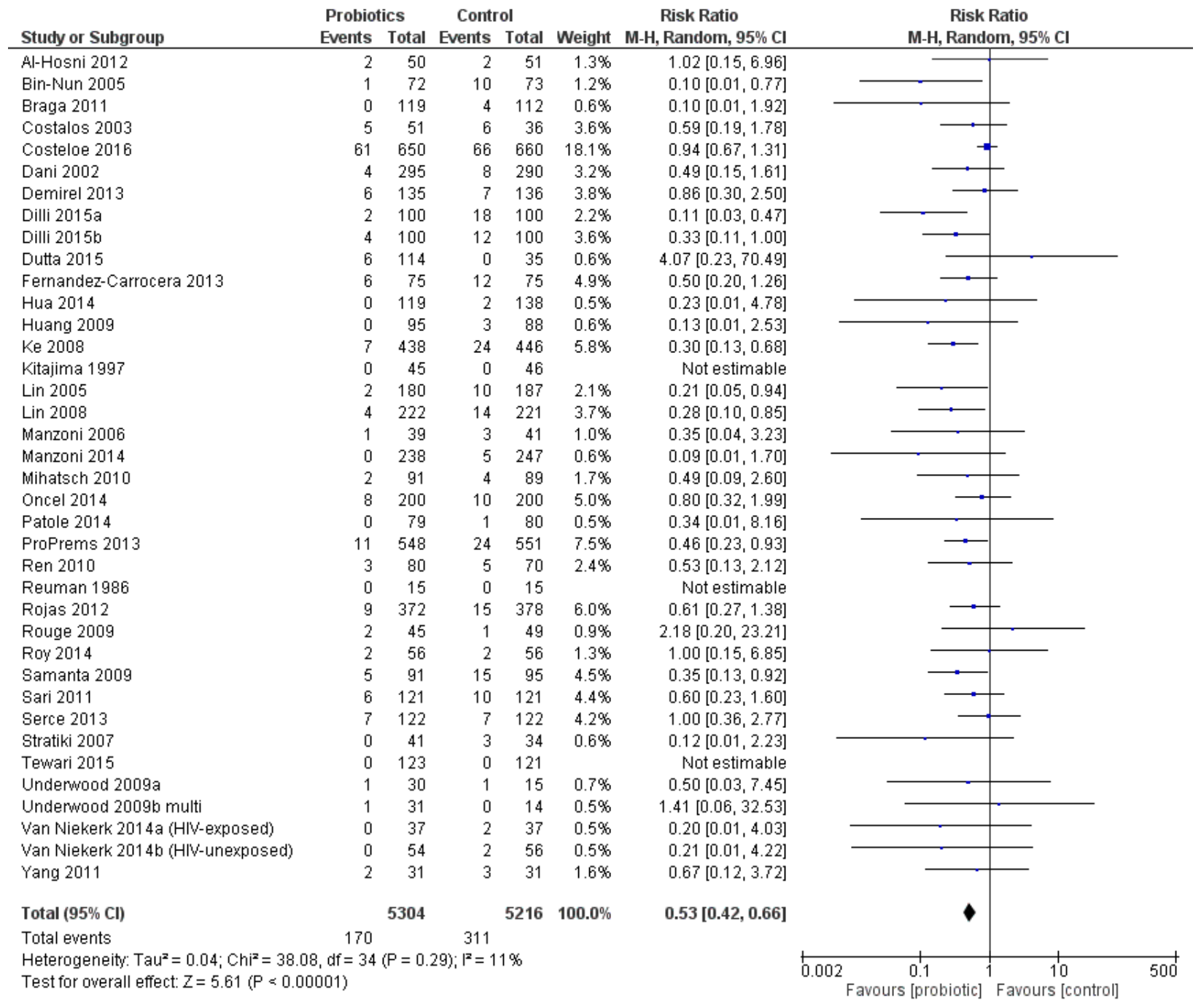




\section{Figure 3 (on next page)}

Forest plot showing the effect of probiotics on culture-proven sepsis in all infants 


\begin{tabular}{|c|c|c|c|c|c|}
\hline \multirow[b]{2}{*}{ Study or Subgroup } & \multicolumn{2}{|c|}{ Probiotics } & \multicolumn{2}{|c|}{ Control } & \multirow[b]{2}{*}{ Weight } \\
\hline & Events & Total & Events & Total & \\
\hline Al-Hosni 2012 & 13 & 50 & 16 & 51 & $3.3 \%$ \\
\hline Bin-Nun 2005 & 31 & 72 & 24 & 73 & $5.5 \%$ \\
\hline Costalos 2003 & 3 & 51 & 3 & 36 & $0.7 \%$ \\
\hline Costeloe 2016 & 73 & 650 & 77 & 660 & $7.6 \%$ \\
\hline Dani 2002 & 14 & 295 & 12 & 290 & $2.4 \%$ \\
\hline Demirel 2013 & 20 & 135 & 21 & 136 & $3.8 \%$ \\
\hline Dilli 2015a & 8 & 100 & 13 & 100 & $2.1 \%$ \\
\hline Dilli 2015b & 8 & 100 & 10 & 100 & $1.9 \%$ \\
\hline Dutta 2015 & 10 & 114 & 6 & 35 & $1.7 \%$ \\
\hline Fernandez-Carrocera 2013 & 42 & 75 & 44 & 75 & $8.2 \%$ \\
\hline Hua 2014 & 2 & 119 & 8 & 138 & $0.7 \%$ \\
\hline $\operatorname{Lin} 2005$ & 22 & 180 & 36 & 187 & $4.6 \%$ \\
\hline Lin 2008 & 40 & 222 & 24 & 221 & $4.8 \%$ \\
\hline Manzoni 2006 & 19 & 39 & 22 & 41 & $5.4 \%$ \\
\hline Manzoni 2009 & 7 & 151 & 9 & 153 & $1.6 \%$ \\
\hline Millar 1993 & 0 & 10 & 0 & 10 & \\
\hline Oncel 2014 & 13 & 200 & 25 & 200 & $3.1 \%$ \\
\hline Patole 2014 & 17 & 79 & 12 & 80 & $2.9 \%$ \\
\hline ProPrems 2013 & 72 & 548 & 89 & 551 & $7.9 \%$ \\
\hline Rojas 2012 & 24 & 372 & 17 & 378 & $3.4 \%$ \\
\hline Romeo 2011a & 1 & 83 & 5 & 42 & $0.4 \%$ \\
\hline Romeo 2011b & 2 & 83 & 4 & 41 & $0.6 \%$ \\
\hline Rouge 2009 & 15 & 45 & 13 & 49 & $3.3 \%$ \\
\hline Roy 2014 & 31 & 56 & 42 & 56 & $8.1 \%$ \\
\hline Samanta 2009 & 13 & 91 & 28 & 95 & $3.5 \%$ \\
\hline Sari 2011 & 29 & 121 & 26 & 121 & $4.9 \%$ \\
\hline Serce 2013 & 19 & 122 & 25 & 122 & $4.0 \%$ \\
\hline Stratiki 2007 & 0 & 41 & 3 & 34 & $0.2 \%$ \\
\hline Tewari 2015 & 8 & 123 & 11 & 121 & $1.9 \%$ \\
\hline Van Niekerk 2014a (HIV-exposed) & 2 & 37 & 4 & 37 & $0.6 \%$ \\
\hline Van Niekerk 2014b (HV-unexposed) & 5 & 54 & 4 & 56 & $1.0 \%$ \\
\hline Total $(95 \% \mathrm{Cl})$ & & 4418 & & 4289 & $100.0 \%$ \\
\hline Total events & 563 & & 633 & & \\
\hline $\begin{array}{l}\text { Heterogeneity: } \operatorname{Tau}^{2}=0.03 ; \mathrm{Chi}^{2}=42 . \\
\text { Test for overall effect: } Z=1.94(P=0.0\end{array}$ & $\mathrm{df}=29$ & $(P=0.0$ & $06) ;\left.\right|^{2}=3$ & & \\
\hline
\end{tabular}

Risk Ratio

Risk Ratio

Study or Subgroup

Random, 95\% Cl

M-H, Random, 95\% C

$\% \quad 0.83[0.45,1.54]$

$1.31[0.86,2.00]$

$0.71[0.15,3.30]$

$0.96[0.71,1.30]$

$1.15[0.54,2.44]$

$0.96[0.55,1.69]$

$0.62[0.27,1.42]$

$0.80[0.33,1.94]$

$0.51[0.20,1.31]$

$0.95[0.72,1.26]$

$0.29[0.06,1.34]$

$0.63[0.39,1.04]$

$1.66[1.04,2.66]$

$0.91[0.59,1.40]$

$0.79[0.30,2.06]$

Not estimable

$0.52[0.27,0.99]$

$1.43[0.73,2.80]$

$0.81[0.61,1.08]$

$1.43[0.78,2.63]$

$0.10[0.01,0.84]$

$0.25[0.05,1.29]$

$1.26[0.67,2.34]$

$0.74[0.56,0.98]$

$0.48[0.27,0.88]$

$1.12[0.70,1.78]$

$0.76[0.44,1.31]$

$0.12[0.01,2.23]$

$0.72[0.30,1.72]$

$0.50[0.10,2.56]$

$1.30[0.37,4.57]$

$0.88[0.77,1.00]$

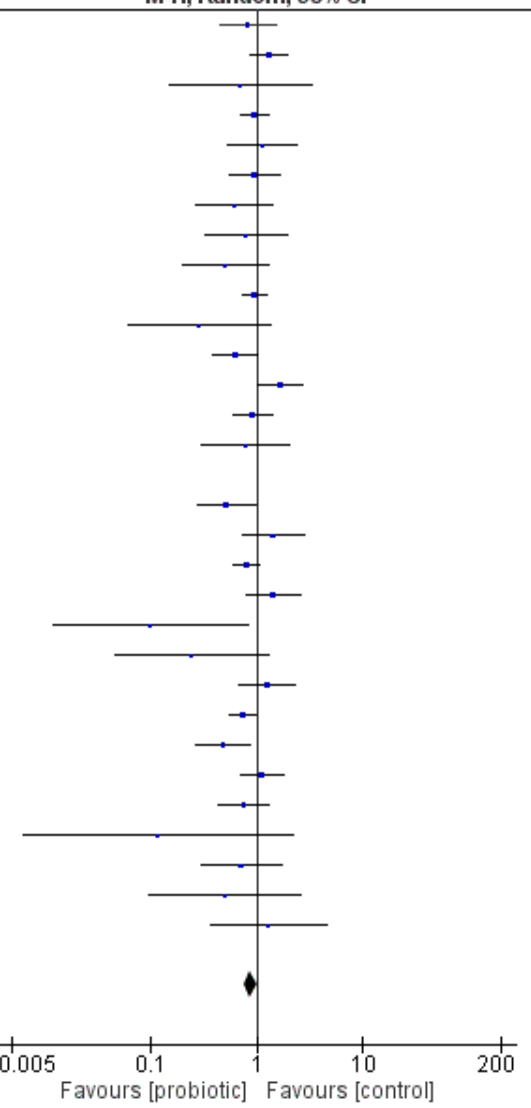


Figure 4(on next page)

Forest plot showing the effect of probiotics on all-cause mortality in all infants 


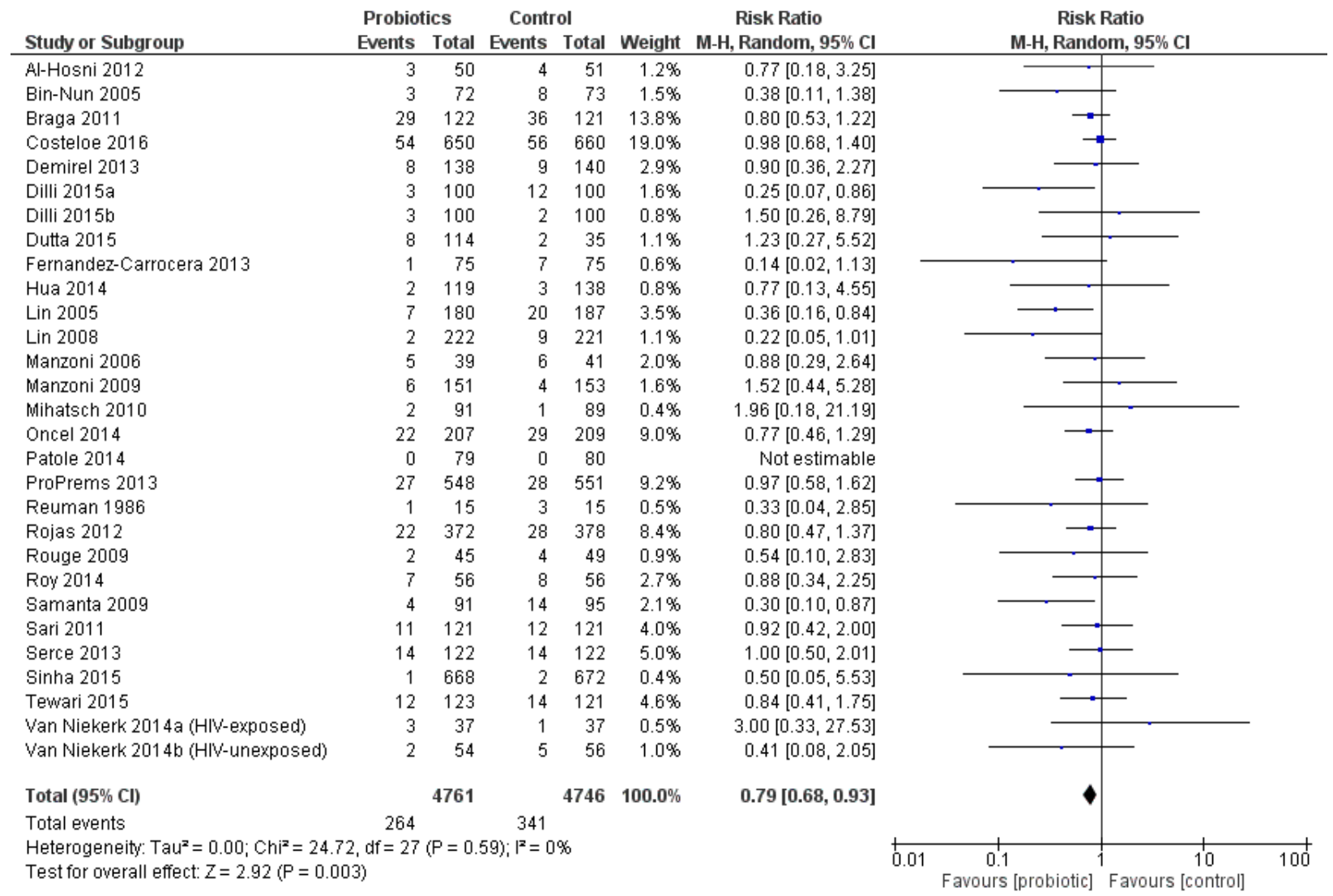


Figure $\mathbf{5}$ (on next page)

Forest plot showing the effect of probiotics in VLBW infants 


\begin{tabular}{|c|c|c|c|c|c|c|c|c|c|c|}
\hline Study or Subgroup & \multicolumn{2}{|c|}{ Probiotics } & \multicolumn{2}{|c|}{ Control } & Weight & $\begin{array}{c}\text { Risk Ratio } \\
\text { M-H, Random, } 95 \% \mathrm{Cl} \\
\end{array}$ & \multicolumn{3}{|c|}{$\begin{array}{c}\text { Risk Ratio } \\
\text { M-H, Random, } 95 \% \mathrm{Cl} \\
\end{array}$} & \\
\hline Al-Hosni 2012 & 2 & 50 & 2 & 51 & $1.9 \%$ & $1.02[0.15,6.96]$ & & & & \\
\hline Bin-Nun 2005 & 1 & 72 & 10 & 73 & $1.7 \%$ & $0.10[0.01,0.77]$ & & & & \\
\hline Braga 2011 & 0 & 119 & 4 & 112 & $0.8 \%$ & $0.10[0.01,1.92]$ & & & & \\
\hline Dani 2002 & 4 & 295 & 8 & 290 & $4.9 \%$ & $0.49[0.15,1.61]$ & & & - & \\
\hline Demirel 2013 & 6 & 135 & 7 & 136 & $6.1 \%$ & $0.86[0.30,2.50]$ & & & & \\
\hline Dilli $2015 a$ & 2 & 100 & 18 & 100 & $3.4 \%$ & $0.11[0.03,0.47]$ & & & & \\
\hline Dilli 2015b & 4 & 100 & 12 & 100 & $5.7 \%$ & $0.33[0.11,1.00]$ & & & & \\
\hline Fernandez-Carrocera 2013 & 6 & 75 & 12 & 75 & $8.0 \%$ & $0.50[0.20,1.26]$ & & & & \\
\hline Kitajima 1997 & 0 & 45 & 0 & 46 & & Not estimable & & & & \\
\hline Lin 2005 & 2 & 180 & 10 & 187 & $3.1 \%$ & $0.21[0.05,0.94]$ & & & & \\
\hline $\operatorname{Lin} 2008$ & 4 & 217 & 14 & 217 & $5.8 \%$ & $0.29[0.10,0.85]$ & & & & \\
\hline Manzoni 2006 & 1 & 39 & 3 & 41 & $1.4 \%$ & $0.35[0.04,3.23]$ & & & & \\
\hline Manzoni 2014 & 0 & 238 & 5 & 247 & $0.8 \%$ & $0.09[0.01,1.70]$ & & & - & \\
\hline Mihatsch 2010 & 2 & 91 & 4 & 89 & $2.5 \%$ & $0.49[0.09,2.60]$ & & & & \\
\hline Oncel 2014 & 8 & 200 & 10 & 200 & $8.4 \%$ & $0.80[0.32,1.99]$ & & & - & \\
\hline Patole 2014 & 0 & 79 & 1 & 80 & $0.7 \%$ & $0.34[0.01,8.16]$ & & & & \\
\hline ProPrems 2013 & 11 & 548 & 24 & 551 & $13.9 \%$ & $0.46[0.23,0.93]$ & & & & \\
\hline Rojas 2012 & 6 & 176 & 10 & 184 & $7.0 \%$ & $0.63[0.23,1.69]$ & & & - & \\
\hline Rouge 2009 & 2 & 45 & 1 & 49 & $1.2 \%$ & $2.18[0.20,23.21]$ & & & & \\
\hline Samanta 2009 & 5 & 91 & 15 & 95 & $7.3 \%$ & $0.35[0.13,0.92]$ & & & & \\
\hline Sari 2011 & 6 & 110 & 10 & 111 & $7.2 \%$ & $0.61[0.23,1.61]$ & & & 一 & \\
\hline Serce 2013 & 7 & 122 & 7 & 122 & $6.7 \%$ & $1.00[0.36,2.77]$ & & & & \\
\hline Tewari 2015 & 0 & 61 & 0 & 59 & & Not estimable & & & & \\
\hline Van Niekerk 2014a (HIV-exposed) & 0 & 37 & 2 & 37 & $0.8 \%$ & $0.20[0.01,4.03]$ & & & & \\
\hline Van Niekerk 2014b (HIV-unexposed) & 0 & 54 & 2 & 56 & $0.8 \%$ & $0.21[0.01,4.22]$ & & & & \\
\hline Total $(95 \% \mathrm{Cl})$ & & 3279 & & 3308 & $100.0 \%$ & $0.47[0.36,0.61]$ & & & & \\
\hline Total events & 79 & & 191 & & & & & & & \\
\hline $\begin{array}{l}\text { Heterogeneity: } \mathrm{Tau}^{2}=0.00 ; \mathrm{Chi}^{2}=19 . \\
\text { Test for overall effect: } Z=5.67(\mathrm{P}=0.0\end{array}$ & $\begin{array}{l}9, d f=22 \\
001)\end{array}$ & $(P=0$. & $60) ; 1^{2}=0$ & & & & 0.005 & 50.1 & 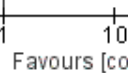 & $200^{\circ}$ \\
\hline
\end{tabular}


Figure $\mathbf{6}$ (on next page)

Forest plot showing the effect of probiotics in ELBW infants 


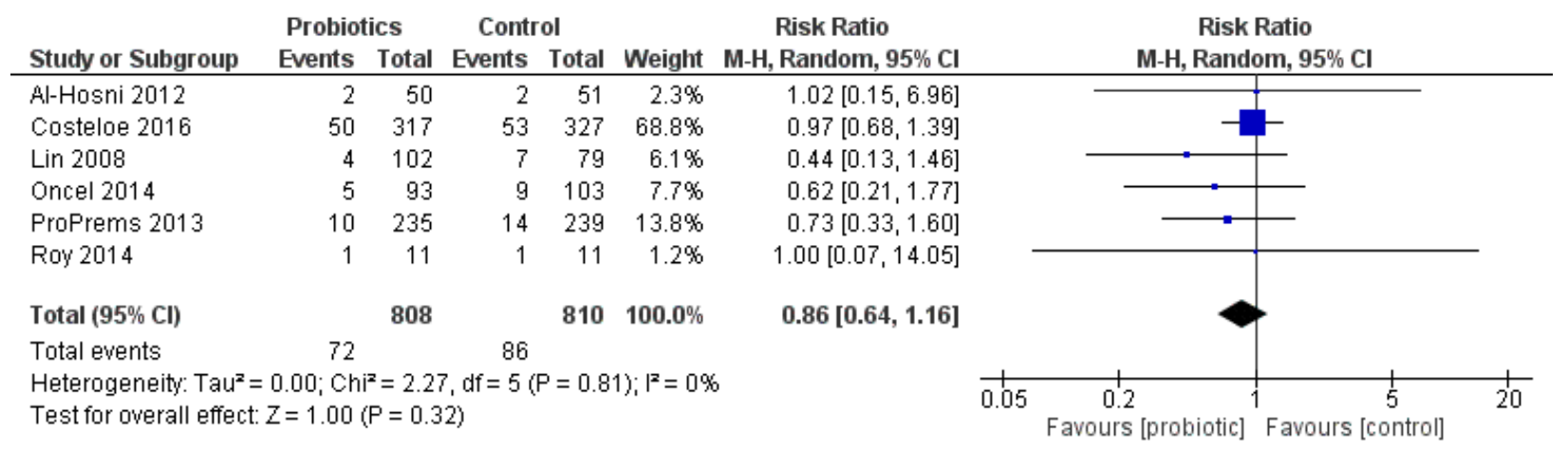

